\title{
The Relationship between Myoglobin, Aerobic Capacity, Nitric Oxide Synthase Activity and Mitochondrial Function in Fish Hearts
}

\author{
Lucie Gerber ${ }^{*}{ }^{\circledR}\left(\mathbb{D}\right.$, Kathy A. Clow ${ }^{\dagger}$, William R. Driedzic and Anthony K. Gamperl \\ Department of Ocean Sciences, Memorial University, St. John's, NL A1C 5S7, Canada; kclow@mun.ca (K.A.C.); \\ driedzic@mun.ca (W.R.D.); kgamperl@mun.ca (A.K.G.) \\ * Correspondence: lucie.gerber@ibv.uio.no \\ + Indicates that these authors contributed equally to this work.
}

check for

updates

Citation: Gerber, L.; Clow, K.A.; Driedzic, W.R.; Gamperl, A.K. The Relationship between Myoglobin, Aerobic Capacity, Nitric Oxide

Synthase Activity and Mitochondrial Function in Fish Hearts. Antioxidants 2021, 10, 1072. https://doi.org/ $10.3390 /$ antiox 10071072

Academic Editors: Maria

Carmela Cerra, Sandra Imbrogno and Alfonsina Gattuso

Received: 1 June 2021

Accepted: 30 June 2021

Published: 3 July 2021

Publisher's Note: MDPI stays neutral with regard to jurisdictional claims in published maps and institutional affiliations.

Copyright: (c) 2021 by the authors. Licensee MDPI, Basel, Switzerland. This article is an open access article distributed under the terms and conditions of the Creative Commons Attribution (CC BY) license (https:// creativecommons.org/licenses/by/ $4.0 /)$.

\begin{abstract}
The dynamic interactions between nitric oxide (NO) and myoglobin (Mb) in the cardiovascular system have received considerable attention. The loss of $\mathrm{Mb}$, the principal $\mathrm{O}_{2}$ carrier and a NO scavenger/producer, in the heart of some red-blooded fishes provides a unique opportunity for assessing this globin's role in NO homeostasis and mitochondrial function. We measured Mb content, activities of enzymes of NO and aerobic metabolism [NO Synthase (NOS) and citrate synthase, respectively] and mitochondrial parameters [Complex-I and -I+II respiration, coupling efficiency, reactive oxygen species production/release rates and mitochondrial sensitivity to inhibition by NO (i.e., $\left.\left.\mathrm{NO} \mathrm{IC}_{50}\right)\right]$ in the heart of three species of red-blooded fish. The expression of $\mathrm{Mb}$ correlated positively with NOS activity and NO IC 50 , with low NOS activity and a reduced NO $\mathrm{IC}_{50}$ in the $\mathrm{Mb}$-lacking lumpfish (Cyclopterus lumpus) as compared to the Mb-expressing Atlantic salmon (Salmo salar) and short-horned sculpin (Myoxocephalus scorpius). Collectively, our data show that NO levels are fine-tuned so that $\mathrm{NO}$ homeostasis and mitochondrial function are preserved; indicate that compensatory mechanisms are in place to tightly regulate [NO] and mitochondrial function in a species without $\mathrm{Mb}$; and strongly suggest that the $\mathrm{NO} \mathrm{IC}_{50}$ for oxidative phosphorylation is closely related to a fish's hypoxia tolerance.
\end{abstract}

Keywords: mitochondrial respiration; reactive oxygen species; nitric oxide; citrate synthase activity; salmon; sculpin; lumpfish

\section{Introduction}

Nitric oxide (NO) is a gasotransmitter that is normally produced in a reaction catalyzed by the enzyme $\mathrm{NO}$ synthase (NOS) which requires $\mathrm{O}_{2}$ to oxidize L-arginine, and several cofactors such as tetrahydrobiopterin $\left(\mathrm{H}_{4} \mathrm{~B}\right)$ and nicotinamide adenine dinucleotide phosphate (NADPH) [1]. However, tissue NO levels are also determined by reactions involving metal-containing oxygen binding proteins (e.g., myoglobin, Mb). Under normoxic conditions, $\mathrm{Mb}$ bound to oxygen (oxyMb) reacts with $\mathrm{NO}$ forming metMb and nitrate, whereas under hypoxic/anoxic conditions deoxyMb acts as a nitrite reductase and reduces nitrite to NO [2]. In the heart, at the level of the mitochondrion, this dynamic NO-Mb cycle drives reversible adjustments in respiration, and this optimizes $\mathrm{O}_{2}$ utilization based on intracellular $\mathrm{O}_{2}$ tension while at the same time controlling the level of free radicals [3-5]. NO can reversibly bind to complex-IV (CIV) and result in the S-nitrosation of complex-I (CI), and thus, modulate both mitochondrial $\mathrm{O}_{2}$ consumption and the production of reactive oxygen species (ROS) [6,7]. For example, S-nitrosation of CI was recently shown to decrease both ROS production and CI activity in cardiac mitochondria of the freshwater turtle Trachemys scripta [8]. Hence, the absence of the NO scavenger $\mathrm{Mb}$ may have important implications for ROS production and CI capacity. The dynamic interaction between $\mathrm{NO}$ and $\mathrm{Mb}$ signaling with regard to cardiovascular homeostasis has received considerable 
attention [4,9-11]. Mb is highly expressed in the hearts of many fishes [12] and appears to be the predominant nitrite reductase in the heart of some fish [13]. Yet, the complex relationship between these two chemical entities in controlling $\mathrm{O}_{2}$ and $\mathrm{NO}$ homeostasis (1) is not fully understood, notably at the level of the mitochondrion; and (2) is challenged by the existence of species that naturally lack the $\mathrm{O}_{2}$ carriers hemoglobin $(\mathrm{Hb})$ and/or $\mathrm{Mb}[14,15]$.

The lack of $\mathrm{Mb}$, and therefore the loss of the principal NO degradation mechanism, in some fish hearts [13] may have critical implications for mitochondrial and cardiovascular regulation [16]. Indeed, mitochondrial respiration in the heart of some fish species has been shown to be under a tone from NO [14]. Species that have lost the $\mathrm{Hb}$ - and/or Mb- genes as part of their evolutionary history offer a unique opportunity to study adaptations to the absence of these major $\mathrm{O}_{2}$ carriers and $\mathrm{NO}$ regulators $[17,18]$. The cardiovascular system of globin- $(\mathrm{Mb}$ and /or $\mathrm{Hb})$ lacking/poor fishes has received considerable attention, and comparative studies with globin-expressing/rich fishes have revealed unique cardiovascular changes that compensate for the lack of $\mathrm{O}_{2}$ oxygen carriers and/or a lower blood oxygencarrying capacity $[17,19-23]$. It has been suggested that some of these modifications in the cardiovascular system were triggered by the lack of these principal NO scavengers [4,24]. Indeed, the loss of circulating $\mathrm{Hb}$ was associated with the activity and abundance of NOS in various tissues, and higher basal $\mathrm{NO}$ metabolites (NOx, nitrite and nitrate) in the plasma of Antarctic $\mathrm{Hb}^{-}$icefishes as compared to $\mathrm{Hb}^{+}$species [23,25]. Nonetheless, research is needed on non-Antarctic species, notably on hemoglobin-rich teleosts lacking $\mathrm{Mb}$ (i.e., $\mathrm{Hb}^{+}$ $\mathrm{Mb}^{-}$fishes) $[18,26,27]$ before we can understand the complex role that $\mathrm{Mb}$ plays in both NO homeostasis, and in regulating mitochondrial function, in the heart [5].

Recently, we have been able to measure the [NO] that reduces mitochondrial respiration by $50 \%$ (i.e., mitochondrial sensitivity to $\mathrm{NO}$; its $\mathrm{NO} \mathrm{IC}_{50}$ ), and this parameter appears to display considerable plasticity when fishes respond to changes in energy demand or $\mathrm{O}_{2}$ tension. For example, sablefish (Anoplopoma fimbria) cardiac mitochondria were more sensitive to inhibition by $\mathrm{NO}$ after acclimation to low $\mathrm{O}_{2}$ conditions (i.e., the $\mathrm{NO} \mathrm{IC}_{50}$ decreased [28]), whereas in Atlantic salmon (Salmo salar), cardiac mitochondria were less sensitive to inhibition by $\mathrm{NO}$ after acclimation to elevated temperature $\left(20^{\circ} \mathrm{C}\right.$; i.e., the $\mathrm{NO}$ $\mathrm{IC}_{50}$ increased [29]). This plasticity in mitochondrial sensitivity to NO may play an important role in preserving both $\mathrm{NO}$ and $\mathrm{O}_{2}$ homeostasis, and in protecting cardiac aerobic metabolism in fishes.

Based on the above information/data, we hypothezised: (1) that the loss of Mb has led to adjustments of the NOS/NO system (i.e., NOS activity and mitochondrial NO $\mathrm{IC}_{50}$ ) to optimize the utilization of $\mathrm{O}_{2}$ and mitochondrial function in cardiac tissues; and (2) that a positive correlation exists between mitochondrial $\mathrm{NO}^{\mathrm{IC}} \mathrm{F}_{50}$ and $\mathrm{Mb}$ levels in the fish heart. Collectively, these changes would allow $\mathrm{Mb}$-less fish to overcome the lack of $\mathrm{Mb}$ by slowly generating NO (i.e., reducing NOS activity) and quickly inhibiting mitochondrial respiration (i.e., by increasing the sensitivity to inhibition by NO). These two compensatory mechanisms may allow fish without (or with lower) cardiac Mb levels to rely on NOSgenerated $\mathrm{NO}$ to maintain $\mathrm{O}_{2}$ and $\mathrm{NO}$ gradients at the level of the mitochondria, and to avoid high levels of basal NOx in the absence of $\mathrm{Mb}$.

In this study, we used the hearts of three red-blooded $\left(\mathrm{Hb}^{+}\right)$fishes [one Mb-lacking $\left(\mathrm{Mb}^{-}\right)$species (lumpfish; Cyclopterus lumpus) and two $\mathrm{Mb}$-expressing $\left(\mathrm{Mb}^{+}\right)$fish species, the Atlantic salmon (Salmo salar) and short-horned sculpin (Myoxocephalus scorpius)], which have different ecophysiological traits (including activity levels) to: (1) determine cardiac mitochondrial $\mathrm{O}_{2}$ consumption, $\mathrm{ROS}$ production and mitochondrial sensitivity to inhibition by $\mathrm{NO}\left(\mathrm{NO} \mathrm{IC}_{50}\right)$; (2) measure the activity of NOS and citrate synthase as indicators of NO production and cellular oxidative capacity, respectively; and (3) examine the relationship(s) between cardiac $\mathrm{Mb}$ level, NOS activity and $\mathrm{NO} \mathrm{IC}_{50}$ with regard to the regulation of cardiac mitochondrial function. This comparative analysis provides valuable insights into how $\mathrm{Mb}$ tissue level, NO production and mitochondrial sensitivity to NO interact to adjust 
mitochondrial function and cardiac metabolism to ensure sustained function, and to avoid the damaging effects of excess ROS production.

\section{Materials and Methods}

\subsection{Experimental Animals}

Atlantic salmon (Salmo salar, $\mathrm{Hb}^{+} \mathrm{Mb}^{+}$; from Cape d'Or Sustainable Seafood Inc., NS, Canada) and lumpfish (Cyclopterus lumpus, $\mathrm{Hb}^{+} \mathrm{Mb}^{-}$; reared at the Dr. Joe Brown Aquatic Research Building, JBARB) were held in the JBARB at the Ocean Sciences Centre (OSC, Memorial University of Newfoundland). Short-horned sculpin (Myoxocephalus scorpius, $\mathrm{Hb}^{+} \mathrm{Mb}^{+}$) were collected locally and held in the OSC's aquatic facilities for 3 weeks before experiments. Fish were kept in aerated seawater at $7 \pm 1{ }^{\circ} \mathrm{C}$ and provided with a $12 \mathrm{~h}$ light: $12 \mathrm{~h}$ dark photoperiod. Atlantic salmon and lumpfish were hand fed a commercial marine fish diet (Europa; Skretting Inc., St Andrews, NB, Canada) at $1-1.5 \%$ body mass day $^{-1}$, whereas short-horned sculpins were hand fed chopped herring to satiation bi-weekly.

\subsection{Mitochondrial Isolation}

Isolation of mitochondria was performed as described previously [28]. In brief, after the fish was killed with a blow to the head and the body mass was taken, the heart was dissected out and flushed with $10 \mathrm{~mL}$ of PBS (in mmol L-1: $137 \mathrm{NaCl}, 2.7 \mathrm{KCl}, 1.8 \mathrm{KH}_{2} \mathrm{PO}_{4}$, and $10 \mathrm{Na}_{2} \mathrm{HPO}_{4} ; \mathrm{pH} 7.4$ at $20^{\circ} \mathrm{C}$ ) to remove the blood. The ventricle was then cut in half, rinsed with PBS, blotted dry and weighed. Half of the ventricle was snap-frozen in liquid nitrogen and kept at $-80{ }^{\circ} \mathrm{C}$ for later determination of enzymatic activities and myoglobin content. The other half was homogenized in ice-cold isolation medium (in mmol L${ }^{-1}$ : 230 mannitol; 75 sucrose; 20 HEPES; 1 EGTA; pH 7.4 at $20^{\circ} \mathrm{C}$ ) using six passes of a loosefitting motor driven Teflon pestle. The ventricle homogenate was centrifuged at $800 \times g$ for $10 \mathrm{~min}$ at $4{ }^{\circ} \mathrm{C}$ and the resulting supernatant was centrifuged at $8000 \times \mathrm{g}$ for $10 \mathrm{~min}$ at $4{ }^{\circ} \mathrm{C}$ to pellet the mitochondria. The pellet was then washed twice by gentle re-suspension in ice-cold isolation medium containing $10 \mathrm{mg} \mathrm{mL}^{-1}$ of BSA (CAS 9048-46-8) and centrifuged at $8000 \times g$ for $10 \mathrm{~min}$ at $4{ }^{\circ} \mathrm{C}$. The final pellet was re-suspended in ice-cold respiration medium (in mmol L ${ }^{-1}$ : $160 \mathrm{KCl} ; 30 \mathrm{HEPES} ; 10 \mathrm{KH}_{2} \mathrm{PO}_{4} ; 1.5 \mathrm{MgCl}_{2} ; 1$ EDTA (2 EDTA for sculpin); $10 \mathrm{mg} \mathrm{mL}^{-1} \mathrm{BSA}$ (fatty acid free), $\mathrm{pH} 7.4$ at $20{ }^{\circ} \mathrm{C}$ ) and the mitochondria were kept on ice for $30 \mathrm{~min}$ to rest before use. The protein content of the mitochondrial suspensions was determined using the Bradford assay (Thermo Fisher Scientific, Waltham, MA, USA).

\subsection{Mitochondrial Physiology}

The experimental protocols detailed below are shown in Supplementary Figures S1 and S2. The mitochondrial parameters were measured via high-resolution respirometry using Oroboros Oxygraph-2k instruments $\left(\mathrm{O}_{2} \mathrm{k}\right.$-system, Innsbruck, Austria) and following standard operating procedures $\left(\mathrm{O}_{2} \mathrm{k}-\mathrm{SOPs} ;[30,31]\right)$.

Experiment 1. Measurement of coupled mitochondrial respiration and ROS production/release rate.

In Experiment 1 (see Supplementary Figure S1), we measured the ROS production/release rate along with mitochondrial respiration. The ROS production/release rate was estimated by measuring extra-mitochondrial $\mathrm{H}_{2} \mathrm{O}_{2}$ using the constituents of the Amplex ${ }^{\circledR}$ UltraRed [AmR, Thermo Fisher Scientific, Waltham, MA, USA) detection system (AmR $10 \mu \mathrm{mol} \mathrm{L}{ }^{-1}$, horseradish peroxidase (HRP) $3 \mathrm{U} \mathrm{mL}^{-1}$, and superoxide dismutase (SOD) $\left.25 \mathrm{U} \mathrm{mL}^{-1}\right]$. The ROS signal was calibrated following standard operating procedures $\left(\mathrm{O}_{2} \mathrm{k}-\mathrm{SOPs}\right.$; [32,33]), and with the signal amplification and LED intensity adjusted to 1000 and $500 \mathrm{mV}$, respectively. We injected the cardiac mitochondrial suspensions $\left(0.25 \mathrm{mg}\right.$ protein $\left.\mathrm{mL}^{-1}\right)$ into $100 \%$ air-equilibrated chambers filled with $2 \mathrm{~mL}$ of respiration medium at $12{ }^{\circ} \mathrm{C}$. We followed the SUIT protocol described elsewhere [29], with a few modifications. First, we fueled the electron transport system (ETS) with the complex-I (CI) substrates pyruvate $\left(10 \mathrm{mmol} \mathrm{L}^{-1}\right)$, glutamate $\left(15 \mathrm{mmol} \mathrm{L}^{-1}\right)$ and malate $\left(2 \mathrm{mmol} \mathrm{L}^{-1}\right)$ and a suboptimal concentration of ADP 
$\left(100 \mu \mathrm{mol} \mathrm{L}{ }^{-1}\right)$. Thereafter, we added an optimal concentration of ADP $\left(250 \mu \mathrm{mol} \mathrm{L}^{-1}\right)$ to measure maximal oxidative phosphorylation (OXPHOS, State 3) respiration via CI (OXPHOS-I). After the depletion of ADP, we measured leak respiration (LEAK, State 4) via CI (LEAK-I). We then added the complex-II substrate succinate $\left(5 \mathrm{mmol} \mathrm{L}^{-1}\right)$ and an optimal concentration of ADP $\left(250 \mu \mathrm{mol} \mathrm{L}^{-1}\right)$ to measure maximal OXPHOS respiration via $\mathrm{CI}+\mathrm{II}$ (OXPHOS-I+II). After the depletion of ADP, we measured leak respiration rate via $\mathrm{CI}+\mathrm{CII}$ (LEAK-I+II). These measurements also allowed for the calculation of mitochondrial coupling (i.e., respiratory control ratio, $\mathrm{RCR}=$ State $3 /$ State 4 ) and efficiency (i.e., estimation of phosphorylation to oxidation, $\mathrm{P}: \mathrm{O}$ ratio $\left.=\left[\mathrm{ADP}_{\text {injected }}\right] /\left[\mathrm{O}_{\text {consumed }}\right]\right)$ with both $\mathrm{CI}$ - and $\mathrm{CI}+\mathrm{II}-$ substrates in the presence of $250 \mu \mathrm{mol} \mathrm{L}^{-1} \mathrm{ADP}$. Before terminating the experiment, an excess amount of ADP $\left(500 \mu \mathrm{mol} \mathrm{L}^{-1}\right)$ was added and used as a control for Experiment 2 (see below); i.e., to compare maximal OXPHOS respiration in the absence and presence of NO.

\section{Experiment 2. Measurement of mitochondrial sensitivity to NO.}

In Experiment 2 (see Supplementary Figure S2), we connected NO sensors (ISO-NOP, World Precision Instruments, Sarosota, FL, USA) to the Oroboros Oxygraph-2k following standard operating procedures (O2k-SOP; [34]) to determine the concentration of $\mathrm{NO}$ in the chamber that inhibited $50 \%$ of maximal mitochondrial respiration (i.e., the $\mathrm{NO}^{\mathrm{IC}} 50$ to determine mitochondrial sensitivity to NO). We calibrated the NO sensors following the manufacturer's recommendations [WPI instruction manual, Calibration of NO Sensor by Decomposition of SNAP-Method 2; see [28] for details]. We then followed the SUIT protocol described above (in Experiment 1) with a few modifications to determine the mitochondria's sensitivity to $\mathrm{NO}$ (i.e., the $\mathrm{NO} \mathrm{IC}_{50}$ ). In Experiment 2, after adding an excess amount of ADP $\left(1.2 \mathrm{mmol} \mathrm{L}^{-1}\right)$, the NO donor PAPANONOate $\left(15 \mu \mathrm{mol} \mathrm{L}^{-1}\right.$; prepared immediately prior use, Cayman Chemical, Ann Arbor, MI, USA) was added at $\sim 60 \%$ air saturation to initiate NO release (at $\sim 15 \mathrm{nmol} \mathrm{min}^{-1}$ ) and gradually inhibit maximal OXPHOS-I+II respiration. Once maximal OXPHOS-I+II respiration was inhibited by $\sim 60 \%$, 2-phenyl4, 4, 5, 5,-tetramethylimidazoline-1-oxyl 3-oxide (PTIO $0.02 \mathrm{mmol} \mathrm{L}^{-1}$ ) was added to scavenge NO and stop the PAPANONOate-mediated NO release. This reversal of NO's inhibition of respiration allowed maximal OXPHOS-I+II respiration to be re-established, and the integrity of the outer and inner mitochondrial membranes were then assessed with cytochrome c $\left(10 \mu \mathrm{mol} \mathrm{L}^{-1}\right)$ and NADH $\left(0.5 \mathrm{mmol} \mathrm{L}^{-1}\right)$. Before analysis, the recordings of NO concentration were corrected for baseline and zero drift.

\subsection{Nitric Oxide Synthase Activity}

Nitric oxide synthase catalyzes the oxidation of L-arginine to form NO and L-citrulline [35]. In this assay, NOS activity was quantified spectrophotometrically by utilizing the reaction of $\mathrm{NO}$ with oxyMb to form metMb. The oxidation of the ferroheme to ferriheme was measured as an increase in absorbance at $404 \mathrm{~nm}$ as previously described [36]. The slope of this relationship was used to calculate the amount of NO generated per minute, and the extinction coefficient of $28.1 \mathrm{mmol}^{-1} \mathrm{~cm}^{-1}$ was used to calculate NOS activity in both ventricular homogenates and mitochondrial suspensions. The extinction coefficient was determined by making a standard curve with variable proportions of oxidized/reduced $\mathrm{Mb}$. This assay procedure included taking previously snap-frozen ventricles and homogenizing them in 4 volumes of homogenization buffer [in mmol L ${ }^{-1}$ : 50 Tris, 1 EGTA, 1 EDTA, 1:100 Protease Inhibitor Cocktail (P2714)]. The ventricle homogenate and thawed mitochondrial suspensions were then centrifuged at $12,000 \times g$ for $10 \mathrm{~min}$ and the supernatant collected. In some cases, due to the limited amount of thawed mitochondrial suspensions, supernatants from 2 to 3 individuals had to be combined prior to the measurement of NOS activity. NOS assays were performed at room temperature $\left(22^{\circ} \mathrm{C}\right)$ using a 96-well microplate reader (SpectraMax M2e, Molecular Devices, Sunnyvale, CA, USA). The assay buffer consisted of basic medium (in mmol L-1: 100 HEPES, $1 \mathrm{MgCl}_{2}$ and $1 \mathrm{CaCl}_{2}$, pH 7.4 at $20{ }^{\circ} \mathrm{C}$ ) with $100 \mu \mathrm{mol} \mathrm{L}{ }^{-1}$ of NADPH, $10 \mu \mathrm{mol} \mathrm{L}^{-1}$ of DTT, $25 \mu \mathrm{mol} \mathrm{L}^{-1}$ of oxyMb and $10 \mu \mathrm{mol} \mathrm{L}^{-1}$ of 
$\mathrm{BH}_{4}$. Supernatants were added to the assay mixture and the kinetics were read for $15 \mathrm{~min}$ before the reaction was initiated with $30 \mu \mathrm{mol} \mathrm{L}^{-1}$ of L-arginine. The difference in the slopes before and after L-arginine was calculated, and NOS activity was determined as described above. NOS activities for the ventricular homogenates and mitochondrial suspensions were expressed as nmol $\mathrm{min}^{-1} \mathrm{~g} \mathrm{tissue}^{-1}$ and nmol $\mathrm{min}^{-1} \mathrm{mg}_{\text {protein }}{ }^{-1}$, respectively. The oxyMb in the assay buffer was prepared as described previously [37], with a few modifications. A solution of $1 \mathrm{mmol} \mathrm{L}^{-1}$ of $\mathrm{Mb}$ (from equine skeletal muscle, M0630, Sigma-Aldrich, Mississauga, ON, Canada) was dissolved in basic assay medium. The Mb solution was then reduced by adding $1 \mathrm{mg} \mathrm{mL}^{-1}$ of sodium hydrosulfite. The sodium hydrosulfite was then removed by running $2.5 \mathrm{~mL}$ aliquots down a PD-10 desalting column packed with Sephadex G-25 medium (GE Healthcare, Waukesha, WI, USA) equilibrated with the basic assay medium. The final concentration of $\mathrm{Mb}$ was confirmed by reading the absorbance at $580 \mathrm{~nm}$, and using the extinction coefficient of $14.6 \mathrm{mmol}^{-1} \mathrm{~cm}^{-1}$ [38].

\subsection{Citrate Synthase Activity}

Citrate synthase (CS) activity was measured using the method described previously [39]. Briefly, a snap-frozen piece of ventricle was homogenized in ice-cold homogenization buffer $\left(25 \mathrm{mmol} \mathrm{L}{ }^{-1}\right.$ HEPES, $2 \mathrm{mmol} \mathrm{L}^{-1}$ EDTA and $0.5 \%$ Triton X-100, $\mathrm{pH} 7.0$ at $20^{\circ} \mathrm{C}$ ) using a Polytron homogenizer (Kinematica Inc., Bohemia, NY, USA). The resulting homogenate was centrifuged at $2000 \times g$ for 5 min at $4{ }^{\circ} \mathrm{C}$, and $\mathrm{CS}$ activity was measured at room temperature $\left(22^{\circ} \mathrm{C}\right)$ using a 96-well microplate reader (SpectraMax M2e). Ventricular CS activities were expressed as $\mu \mathrm{mol} \mathrm{min}^{-1} \mathrm{~g}$ tissue ${ }^{-1}$.

\subsection{Myoglobin Content}

Myoglobin content [Mb] in the ventricle was measured as described previously [40], with a few modifications. Briefly, a snap-frozen piece of ventricle was homogenized (in 25 mmol L ${ }^{-1}$ HEPES and $2 \mathrm{mmol} \mathrm{L}^{-1}$ EDTA) using a Polytron homogenizer and centrifuged at $10,000 \times g$ for $15 \mathrm{~min}$. The supernatant was then collected, and $1 \mathrm{mg} \mathrm{mL}^{-1}$ of sodium hydrosulfite was added to reduce all the $\mathrm{Mb}$ in the sample. A wavelength scan from 450 to $600 \mathrm{~nm}$ was conducted, and the absorbance at the peak of $580 \mathrm{~nm}$ recorded. $[\mathrm{Mb}]$ was calculated as the $\triangle \mathrm{ABS}$ from the peak to an interpolated baseline. [Mb] was expressed as nmol $\mathrm{g}$ tissue ${ }^{-1}$ using an extinction coefficient of $14.6 \mathrm{mmol}^{-1} \mathrm{~cm}^{-1}$.

\subsection{Chemicals}

All chemicals used in the above procedures were purchased from Sigma-Aldrich (Mississauga, ON, Canada), unless stated otherwise in the method section.

\subsection{Statistical Analyses}

Differences between groups were analyzed using one-way ANOVAs (except for the data for the NO inhibition curves where a two-way ANOVA was used) followed by Tukey's HSD multiple comparison tests. In addition, linear pairwise regressions and non-linear curve fitting were used to examine the relationships between a number of the measured parameters. These analyses were performed using Prism 8 software (GraphPad Inc., La Jolla, CA, USA). In all cases, a $p<0.05$ was considered significant.

\section{Results}

\subsection{Ventricular Characteristics}

Relative ventricular mass (RVM) was $\sim 2$-fold higher in sculpin ( $\sim 0.15 \%)$ compared to salmon and lumpfish ( 0.075-0.079\%; Table 1$)$. The Mb content of the ventricle in salmon and sculpin was comparable $\left(\sim 26.5\right.$ and $20 \mathrm{nmol} \mathrm{g}$ tissue $\left.{ }^{-1}\right)$, whereas this parameter was not detectable in the ventricle of lumpfish (Table 1). Finally, ventricular CS activity was significantly different between all three species (Table 1). The highest CS activity was measured in salmon $\left(6.5 \pm 0.3 \mu \mathrm{mol} \mathrm{g}\right.$ tissue $\left.{ }^{-1} \mathrm{~min}^{-1}\right)$, with values for the sculpin and lumpfish of $5.1 \pm 0.2$ and $3.8 \pm 0.2 \mu \mathrm{mol} \mathrm{g}$ tissue ${ }^{-1} \mathrm{~min}^{-1}$, respectively. 
Table 1. Ventricular characteristics of the experimental species.

\begin{tabular}{cccc}
\hline & S. salar & M. scorpius & C. lumpus \\
\hline Relative ventricular mass (\%) & $0.075 \pm 0.004^{\mathrm{a}}$ & $0.149 \pm 0.010^{\mathrm{b}}$ & $0.079 \pm 0.004^{\mathrm{a}}$ \\
Myoglobin content (nmol g tissue ${ }^{-1}$ ) & $26.49 \pm 4.6^{\mathrm{a}}$ & $20.05 \pm 2.1^{\mathrm{a}}$ & $\mathrm{ND}^{\mathrm{b}}$ \\
Citrate synthase activity $(\mu \mathrm{mol} g$ & $6.48 \pm 0.34^{\mathrm{a}}$ & $3.81 \pm 0.23^{\mathrm{b}}$ & $5.08 \pm 0.23^{\mathrm{c}}$ \\
tissue $^{-1}$ min $^{-1}$ ) & & & \\
\hline
\end{tabular}

Values are means \pm s.e.m., $n=7$ per group; except for Mb content where $n=8-11$ per group (Mb content was measured in additional fishes due to the magnitude of intra-individual variability). Values without a letter in common are significantly $(p<0.05)$ different; one-way ANOVAs followed by Tukey's HSD multiple comparison tests. ND, not detectable.

\subsection{Mitochondrial Respiration and Coupling}

OXPHOS-I (State 3) respiration was $20 \%$ lower in lumpfish as compared to salmon, whereas the OXPHOS-I respiration for sculpin fell between those for these two species (Figure 1A). While LEAK-I (State 4 ) respiration was $~ 25 \%$ lower in sculpin as compared to salmon, this parameter in lumpfish was not significantly different from that measured in either of the two other species (Figure 1B). In contrast, the OXPHOS-I+II and LEAK$\mathrm{I}+\mathrm{II}$ respiration were comparable between all species (Figure 1A,B). The species-specific differences in OXPHOS-I and LEAK-I resulted in 25\% lower respiratory control ratio values (RCR-I) in lumpfish ( 16) as compared to sculpin ( 22), whereas the value for salmon was intermediate and not significantly different ( 18.5) (Figure 1C). RCR-I+II values were not significantly different between species ( 7.5-8; Figure 1C). With regards to $\mathrm{P}: \mathrm{O}$ ratios for mitochondrial oxidative phosphorylation, values were $\sim 3.0-3.5$ with $\mathrm{CI}$ substrates and 2.5-3 with CI+II substrates, and $20 \%$ higher in short-horned sculpin as compared to salmon and lumpfish (Figure 1D).
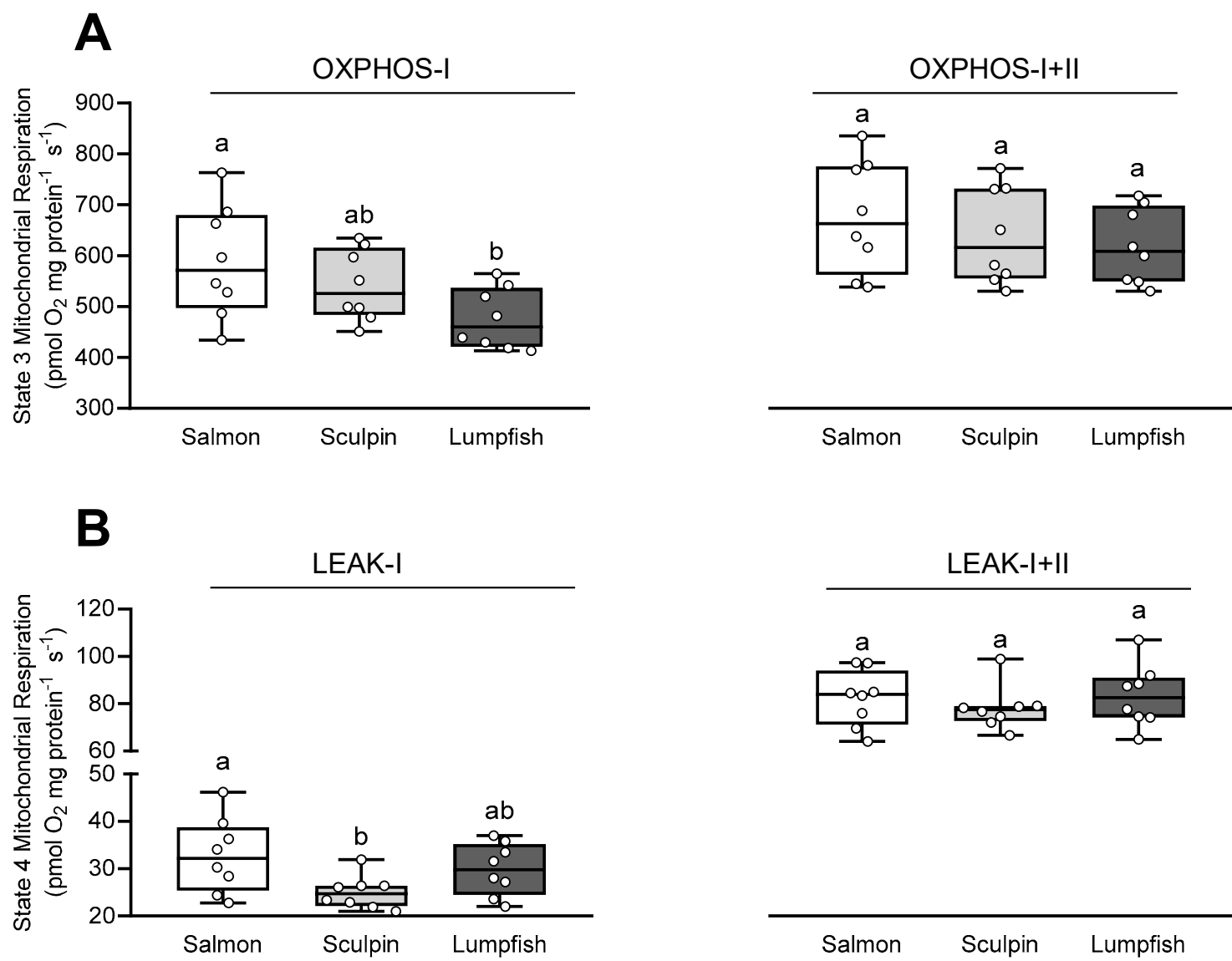

Figure 1. Cont.

$$
\text { Salmon Sculpin Lumpfish }
$$



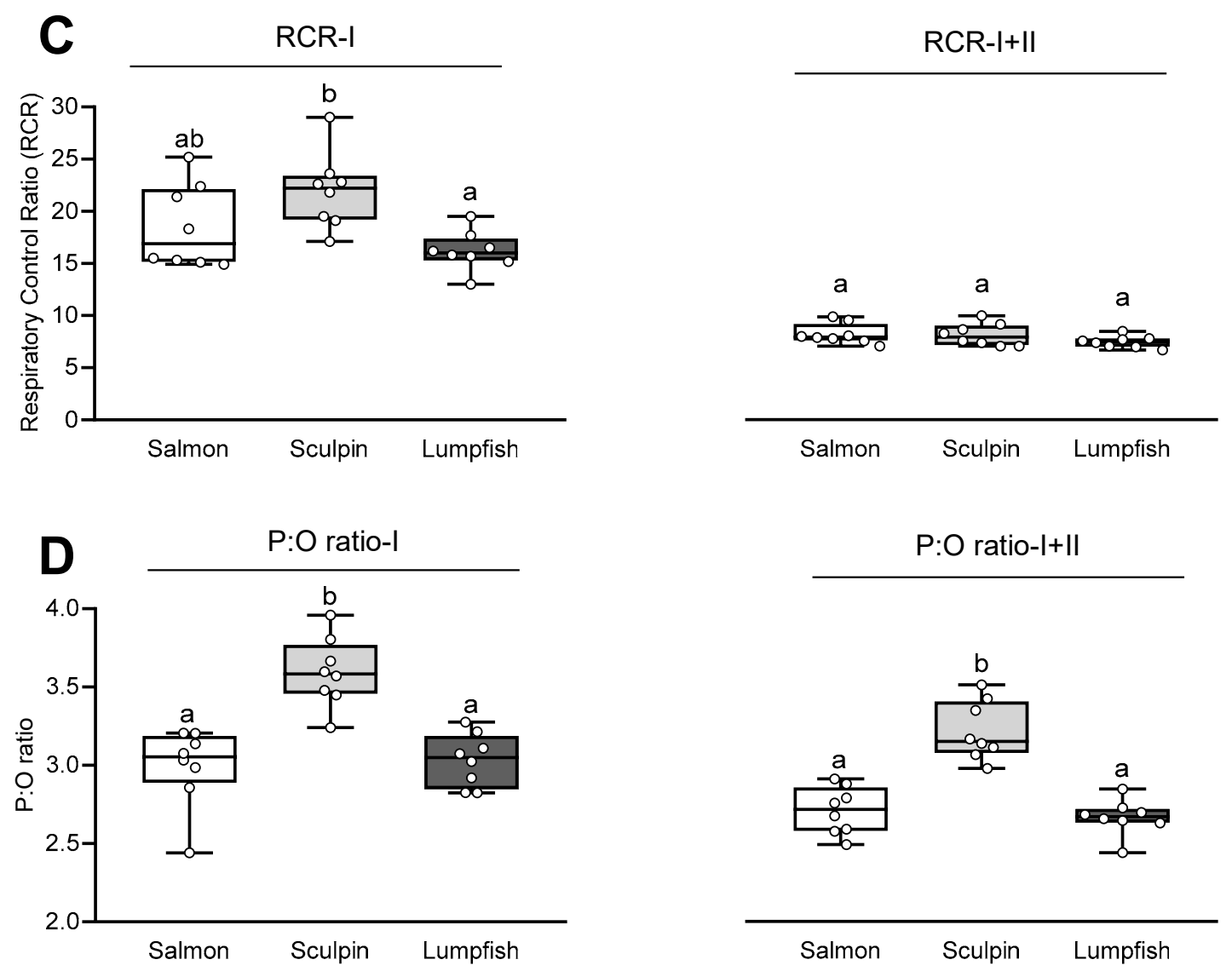

Figure 1. Respiration rates and respiratory control ratios (RCRs) for cardiac mitochondria of Atlantic salmon, short-horned sculpin and lumpfish. (A) Oxidative phosphorylation (OXPHOS, State 3) respiration rates and (B) LEAK respiration rates (State 4) measured with the complex-I (-I) substrates pyruvate, glutamate and malate, and the complex-I+II (-I+II) substrates pyruvate, glutamate, malate and succinate. (C) The resulting RCR (State 3/State 4 values) and (D) estimated P:O ratio $\left(\left[\mathrm{ADP}_{\text {injected }}\right] /\left[\mathrm{O}_{\text {consumed }}\right]\right)$. Values without a letter in common are significantly $(p<0.05)$ different; one-way ANOVAs followed by Tukey's HSD multiple comparison tests. Values are displayed in box-and-whisker-plots; the horizontal line in each box indicates the median value, whereas the top and bottom of the box represent the 25th and 75th percentiles respectively, and the whiskers indicate the highest and lowest values recorded. Symbols represent individual values $(n=8$ per group).

\subsection{Mitochondrial Reactive Oxygen Species (ROS) Production/Release Rate}

The ROS production/release rate (estimated as $\% \mathrm{H}_{2} \mathrm{O}_{2}$ flux $/ \mathrm{O}_{2}$ flux) during OXPHOSI was $\sim 25 \%$ higher in sculpin as compared to salmon, whereas the ROS production/release rate for lumpfish fell between those for salmon and sculpin (Figure 2A). In addition, when expressed as pmol $\mathrm{H}_{2} \mathrm{O}_{2} \mathrm{mg}$ protein ${ }^{-1} \mathrm{~s}^{-1}$, sculpin had the highest $\mathrm{ROS}$ production/release rate during OXPHOS-I (Figure $2 \mathrm{~B}$ ). This parameter was $\sim 10 \%$ higher (but not significantly; $p=0.12)$ as compared to salmon and $\sim 20 \%$ greater than that in lumpfish ( $p=0.01$; Figure $2 \mathrm{~B})$. In contrast, the ROS production/release rate was comparable in all species during OXPHOSI+II (Figure 2A,B). 

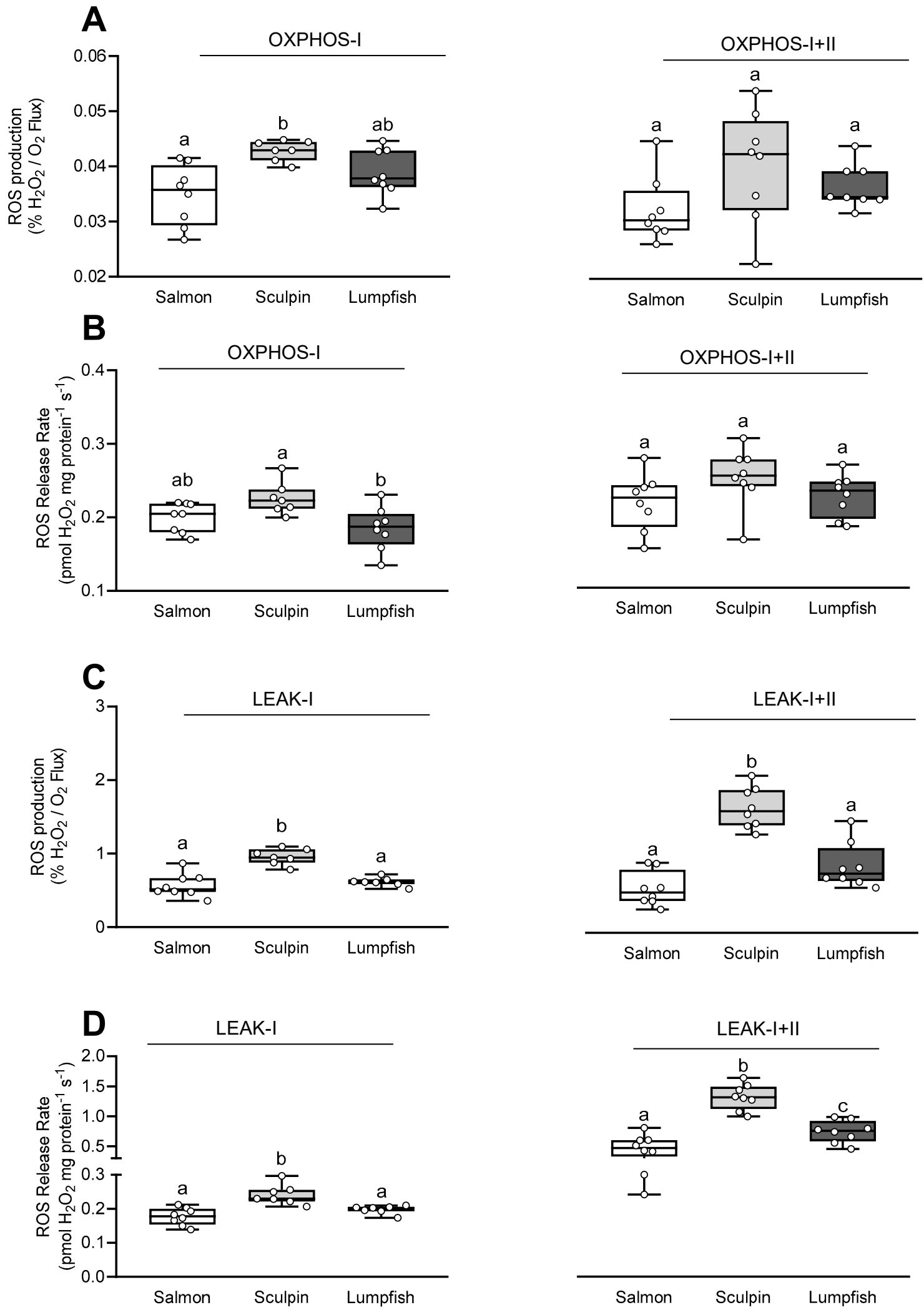

Figure 2. Reactive oxygen species (ROS) production for cardiac mitochondria of Atlantic salmon, short-horned sculpin and lumpfish. The ROS production/release rate during (A,B) oxidative phosphorylation (OXPHOS) and (C,D) LEAK respiration with $\mathrm{CI}$ and $\mathrm{CI}+\mathrm{II}$ substrates, and expressed either as a percentage of mitochondrial $\mathrm{O}_{2}$ consumption $\left(\% \mathrm{H}_{2} \mathrm{O}_{2}\right.$ flux $/ \mathrm{O}_{2}$ flux $(\mathbf{A}, \mathbf{C})$ or as pmol $\mathrm{H}_{2} \mathrm{O}_{2} \mathrm{mg}_{\text {protein }}{ }^{-1} \mathrm{~s}^{-1}(\mathbf{B}, \mathbf{D})$. Other details are as in Figure 1 ( $n=7-8$ per group). Values without a letter in common are significantly $(p<0.05)$ different. 
The ROS production/release rate relative to $\mathrm{O}_{2}$ flux (respiration rate) during both LEAK-I and -I+II was also significantly higher (by $65 \%$ and $90-180 \%$, respectively) in sculpin as compared to both salmon and lumpfish (Figure 2C,D). Further, when expressed relative to respiration (i.e., in $\mathrm{pmol} \mathrm{H}_{2} \mathrm{O}_{2} \mathrm{mg}_{\text {protein }}{ }^{-1} \mathrm{~s}^{-1}$ ), the ROS production/release rate during LEAK-I+II was significantly different between all three species (Figure 2D). The highest rate was measured in sculpin and lowest in salmon, while the ROS production/release rate for lumpfish fell in between.

\subsection{Mitochondrial Integrity and Permeability}

The fractional increase in OXHOS-I+II following the addition of Cyt $\mathrm{c}$ and NADH was never higher than $10 \%$ (i.e., < 0.1 ), and this indicates that there was no inner or outer mitochondrial membrane damage/loss of integrity in any of the mitochondrial preparations (Figure 3). The increase in OXPHOS-I+II respiration following Cyt $\mathrm{c}$ was comparable in all species (5-7\%). However, the increase in OXPHOS-I+II respiration following NADH addition was lower in sculpin and lumpfish (2-3\%) as compared to that measured in salmon $(7 \%)$, and this suggests that salmon had the leakiest inner membrane amongst the three species.
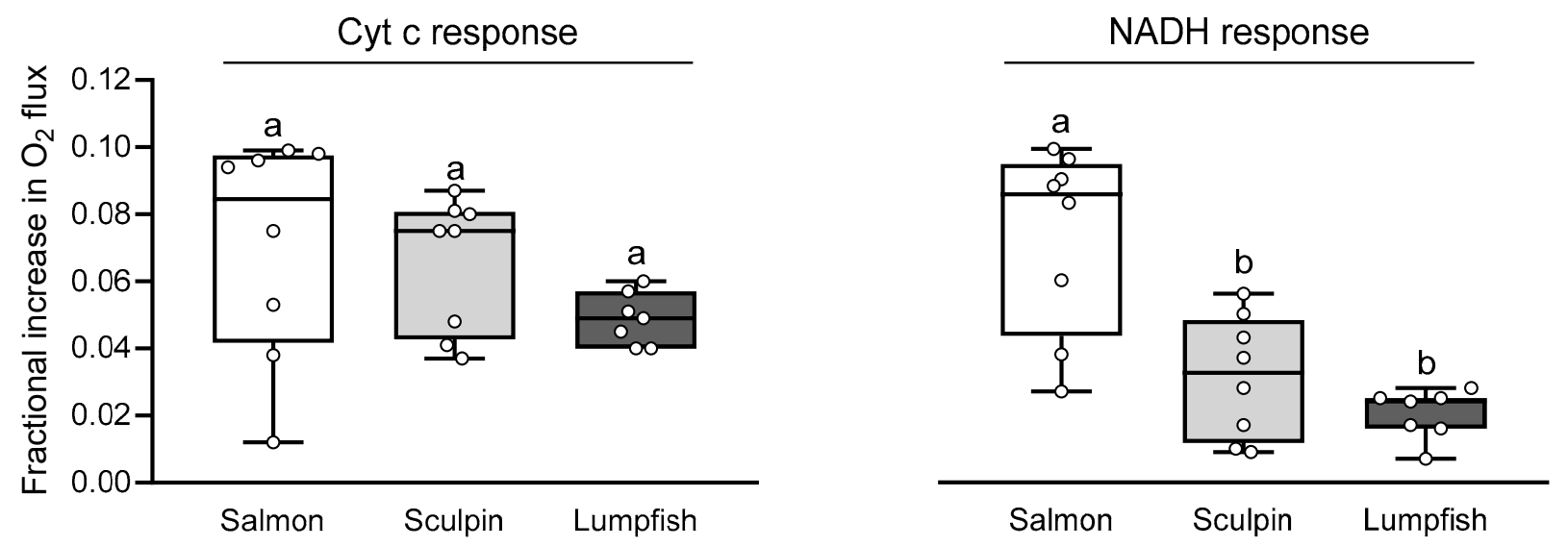

Figure 3. The fractional increase in OXPHOS-I+II respiration of Atlantic salmon, short-horned sculpin and lumpfish cardiac mitochondria following the addition of cytochrome c (Cyt c) and NADH. An increase in $\mathrm{O}_{2}$ flux above 0.1 (10\%) would suggest a loss of membrane integrity. Other details are as in Figure 1 ( $n=7-8$ per group). Values without a letter in common are significantly $(p<0.05)$ different.

\subsection{Mitochondrial Sensitivity to NO}

The release of NO in the chamber gradually inhibited mitochondrial OXPHOS-I+II respiration in all species (Figure 4A). Cardiac mitochondrial OXPHOS-I+II respiration in lumpfish was the most sensitive to inhibition by NO (Figure $4 \mathrm{~A}, \mathrm{~B}$ ). The $\mathrm{NO} \mathrm{IC}_{50}$ value $\left(44.3 \pm 4.6 \mathrm{nmol} \mathrm{L}^{-1}\right)$ for this species was $\sim 35 \%$ lower as compared to that measured in salmon $\left(57.9 \pm 3.6 \mathrm{nmol} \mathrm{L}^{-1}\right)$ and sculpin $\left(66.16 \pm 1.5 \mathrm{nmol} \mathrm{L}^{-1}\right)$ at the same $\mathrm{O}_{2}$ level $\left(100-115 \mu \mathrm{mol} \mathrm{L}^{-1} \mathrm{O}_{2}\right.$ ) (Figure 4B). 
A

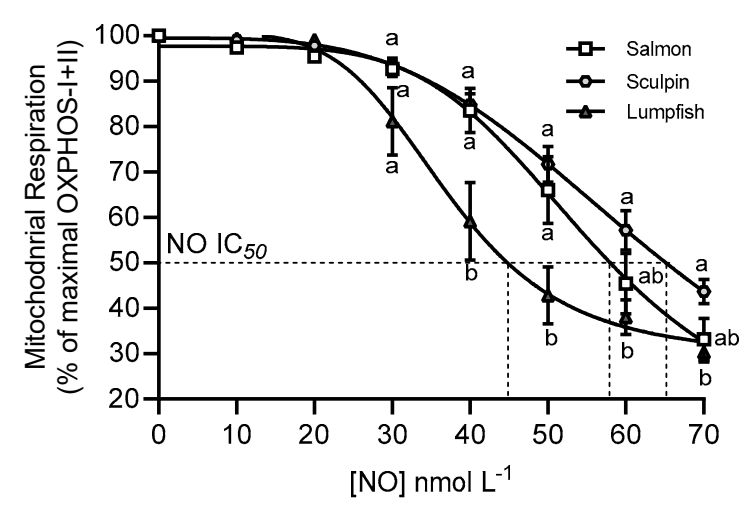

B

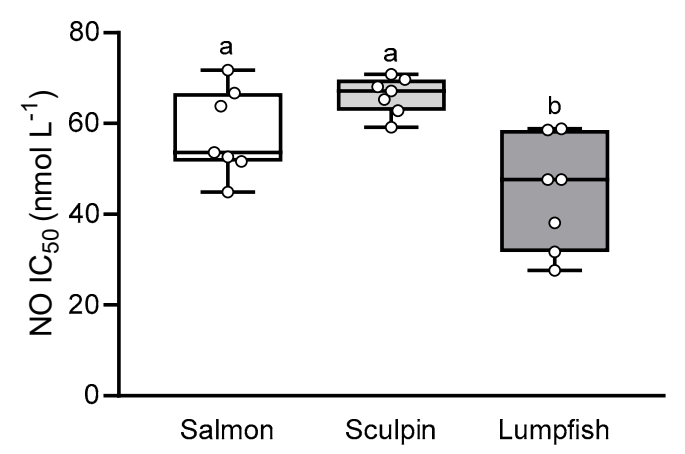

Figure 4. Effect of nitric oxide (NO) on OXPHOS-I+II respiration in cardiac mitochondria of Atlantic salmon, short-horned sculpin and lumpfish. (A) Inhibition of mitochondrial respiration by increasing concentration of NO in the chamber (expressed as a percentage of maximal OXPHOS-I+II). Values are means \pm s.e.m, and values without a letter in common are significantly different $(p<0.05)$ at a specific [NO]. Two-way ANOVA followed by Tukey's HSD multiple comparison tests. (B) Concentration of $\mathrm{NO}$ at which mitochondrial OXPHOS-I+II respiration was half of maximal (NO $\left.\mathrm{IC}_{50}\right)$. Other details are as in Figure 1 ( $n=7$ per group).

\subsection{Ventricular and Mitochondrial NOS Activity}

Ventricular NOS activity in lumpfish $\left(2.2 \pm 0.15 \mathrm{nmol} g\right.$ tissue $\left.{ }^{-1} \mathrm{~min}^{-1}\right)$ was lower (by $\sim 35-45 \%$ ) as compared to that measured in salmon and sculpin $(3.3 \pm 0.21$ and $3.9 \pm 0.27 \mathrm{nmol} \mathrm{g}$ tissue $^{-1} \mathrm{~min}$, respectively; Table 2). Mitochondrial NOS activity was also lowest in lumpfish $\left(0.04 \pm 0.004 \mathrm{nmol} \mathrm{mg}\right.$ protein $\left.{ }^{-1} \mathrm{~min}^{-1}\right)$. However, that for sculpin $\left(0.10 \pm 0.02 \mathrm{nmol} \mathrm{mg}\right.$ protein $\left.{ }^{-1} \mathrm{~min}^{-1}\right)$ was intermediate between that measured for lumpfish and salmon $\left(0.15 \pm 0.01 \mathrm{nmol} \mathrm{mg}\right.$ protein $\left.{ }^{-1} \mathrm{~min}^{-1}\right)$.

Table 2. Nitric oxide synthase (NOS) activity in the ventricle and ventricular mitochondria of the three experimental species.

\begin{tabular}{cccc}
\hline & S. salar & M. scorpius & C. lumpus \\
\hline $\begin{array}{c}\text { Ventricular NOS activity } \\
(\text { nmol g tissue }\end{array}$ min $^{-1}$ ) & $3.30 \pm 0.24^{\mathrm{a}}$ & $3.90 \pm 0.27^{\mathrm{a}}$ & $2.17 \pm 0.15^{\mathrm{b}}$ \\
$\left.\begin{array}{c}\text { Mitochondrial NOS activity } \\
(\text { nmol mg protein }\end{array} \mathrm{min}^{-1}\right)$ & $0.15 \pm 0.010^{\mathrm{a}}$ & $0.10 \pm 0.017^{\mathrm{b}}$ & $0.04 \pm 0.004^{\mathrm{c}}$ \\
\hline
\end{tabular}

Values are means \pm s.e.m., $n=7$ per group; except for mitochondrial NOS activity where some samples were pooled ( 2 to 4 individuals) prior to measurement, and activity was measured in additional fishes; $n=6-8$. Values without a letter in common are significantly $(p<0.05)$ different; one-way ANOVAs followed by Tukey's HSD multiple comparison tests.

\subsection{Relationships between Mb Content, Aerobic Metabolism and the NOS/NO System}

Linear pairwise regressions were used to examine the relationships between a number of the measured parameters of the NOS/NO system (NOS activity, $\mathrm{NO} \mathrm{IC}_{50}$ ) and $\mathrm{Mb}$ content. We found a positive relationship between Mb level in the heart and NOS activity measured in ventricular homogenates and mitochondrial suspensions $\left(R^{2}=0.59, p<0.0001\right.$ and $\mathrm{R}^{2}=0.43, p=0.028$, respectively; Figure $\left.5 \mathrm{~A}, \mathrm{~B}\right)$. A positive relationship was also found between $\mathrm{Mb}$ and mitochondrial $\mathrm{NO} \mathrm{IC}_{50}$ when fitting the data with a non-linear regression $\left(R^{2}=0.47\right.$; Figure $\left.5 C\right)$. In contrast, there was only a weak relationship between the mitochondrial NO $\mathrm{IC}_{50}$ and NOS activity measured in the ventricle homogenates $\left(R^{2}=0.15, p=0.0781\right.$; Figure 5D). Furthermore, NOS activity measured in the mitochondrial suspensions did not correlate with either the mitochondrial $\mathrm{NO} \mathrm{IC} \mathrm{I}_{50}$ or with ventricular NOS activity $\left(R^{2}=0.048, p=0.54\right.$ and $R^{2}=0.10, p=0.28$, respectively; Figure 5E,F). Interestingly, we also found a negative relationship between CS activity (an indicator of 
the aerobic metabolism) and RVM and the mitochondrial P:O ratio $\left(\mathrm{R}^{2}=0.3540, p=0.022\right.$ and $R^{2}=0.37, p=0.0017$, respectively; Supplementary Figure S3).

A

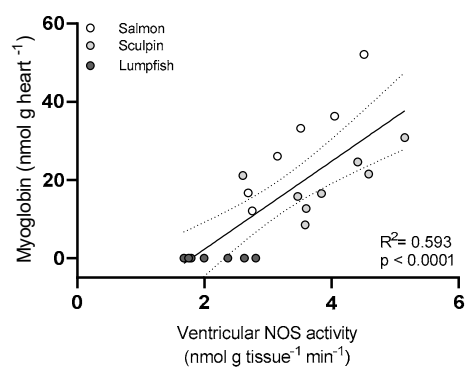

D

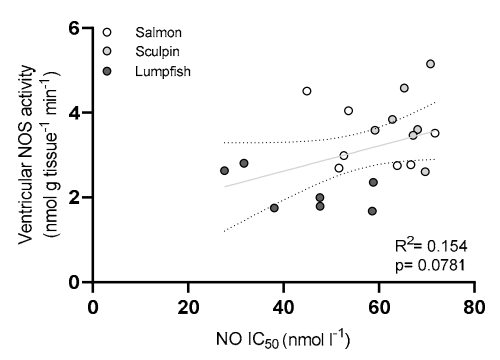

B

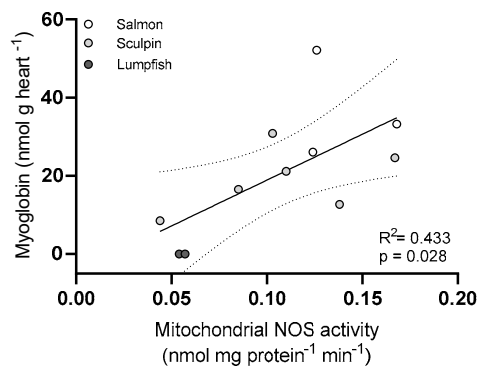

E

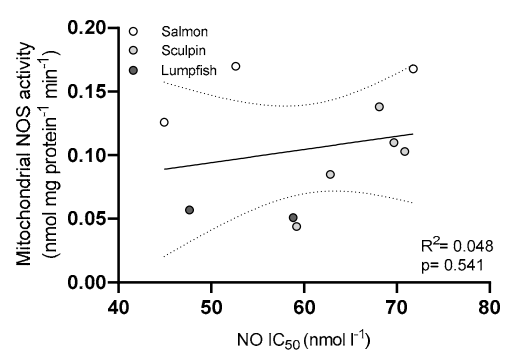

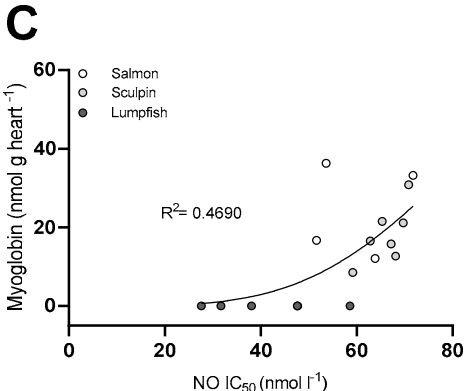

$\mathbf{F}$

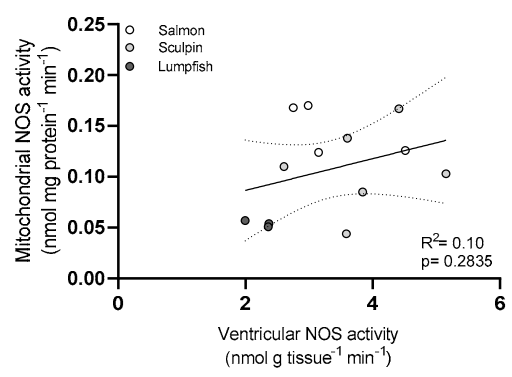

Figure 5. Relationships between heart myoglobin content and the NO/NOS system of Atlantic salmon, short-horned sculpin and lumpfish. Relationship between myoglobin and (A) ventricular NOS activity, (B) mitochondrial NOS activity and $(C)$ mitochondrial sensitivity to inhibition by $\mathrm{NO}\left(\mathrm{NO} \mathrm{IC}_{50}\right)$. (D) Relationship between ventricular NOS activity and NO IC 50 . Relationship between mitochondrial NOS activity and (E) NO IC 50 and (F) ventricular NOS. The solid line represents the overall linear pairwise regression and the dotted lines represent the $95 \%$ confidence limits of the fitted line (except in Panel $\mathrm{C}$ where the solid line represents the best non-linear fit). Circles represent individual values. Values are means \pm s.e.m., $n=2-7$ per group; pooled samples and unpaired values were excluded from these analyses, explaining the lower number of data points for several parameters/groups. Note in Figure $5 \mathrm{C}$ : the salmon with the highest Mb content $\left(52 \mathrm{nmol}\right.$ g heart $\left.^{-1}\right)$ was identified as an outlier when fitting the non-linear regression, and was excluded from this analysis. A $p<0.05$ was considered significant.

\section{Discussion}

Red-blooded fishes without (or differing in) $\mathrm{Mb}$ expression are interesting comparative models for investigating the unique physiological traits that have evolved in species that lack the primary degradative pathway for $\mathrm{NO}$ in the heart, but retain this pathway in the circulatory system (i.e., $\mathrm{Hb}$ ). In this study, we compared mitochondrial function and oxidative capacity in the hearts of three species of red-blooded fish that differ in $\mathrm{Mb}$ content $\left(\mathrm{Hb}^{+} \mathrm{Mb}^{+}\right.$vs. $\left.\mathrm{Hb}^{+} \mathrm{Mb}^{-}\right)$and in physiological traits (e.g., low activity vs. high activity) to examine the role played by $\mathrm{Mb}$ in $\mathrm{NO}$ and $\mathrm{O}_{2}$ homeostasis within cardiac mitochondria and the myocardium.

\subsection{Myoglobin Content}

The $[\mathrm{Mb}]$ in the heart of teleost fishes varies over a considerable range (0 to $\left.488 \mathrm{nmol} \mathrm{g}^{-1} ;[12]\right)$. The $\mathrm{Mb}$ content in the ventricle of Atlantic salmon and short-horned sculpin (26.5 and 20 nmol $\mathrm{g}_{\text {tissue }}{ }^{-1}$, respectively; Table 1) fell toward the low end of this range, and was quite variable. For example, $[\mathrm{Mb}]$ in our salmon ranged from 12 to $52 \mathrm{nmol} g$ tissue $^{-1}$. Variability in heart $[\mathrm{Mb}]$ has previously been reported in Atlantic 
salmon with regards to the region of the heart assayed (spongy vs. cortical), and fish size and maturity (larger vs. smaller hearts, and adult vs. immature salmon) [41]. Specifically, these authors reported $82 \%$ higher $[\mathrm{Mb}]$ in the spongy myocardium than in the cortical myocardium [42], and higher [Mb] in larger hearts from bigger salmon. In addition, [Mb] was $66 \%$ higher in the spongy myocardium of adults than in immature salmon (whose hearts consist mostly of spongy myocardium; [43]). The intraspecific variation in [Mb] observed here may be explained by the uneven distribution of $\mathrm{Mb}$ in the heart of adult salmon and that we only used a small piece of ventricle for the determination of [Mb]. No values of $[\mathrm{Mb}]$ in short-horned sculpin were found in the literature. However, the values reported here were lower than those reported for another sculpin species (Myoxocephalus octodeeimspinosu; $76 \mathrm{nmol} \mathrm{g}^{-1}$, [21]. The variation in [Mb] among sculpin species is in line with variation in traits related to $\mathrm{O}_{2}$ extraction capacity reported among eleven sculpin and related to a species' hypoxia tolerance [44]. Most importantly, myocardial [Mb] were substantially greater in the Atlantic salmon and short-horned sculpin as compared to the lumpfish where it was not detectable; and this is consistent with previous studies [20,21]. The absence vs. presence of $\mathrm{Mb}$ allowed us to study the putative relationships between loss of $\mathrm{Mb}$ and the NOS/NO system in the ventricle of red-blooded fishes, and its consequences for mitochondrial function.

\subsection{Relative Ventricular Mass}

The RVM of the benthic short-horned sculpin was 2-fold greater than in the semipelagic lumpfish or the very active Atlantic salmon (Table 1). Active fishes generally have a larger RVM than benthic fishes [45]. Nonetheless, an RVM twice that of other cold benthic species $(0.06 \%$; [46]) was previously observed in a population of short-horned sculpin endemic to the west coast of Greenland $(0.131-0.124 \%$; [47]). Further, these authors showed that the relatively larger heart of sculpin supports an impressive cardiac performance, which is indeed greater than that of several active species like the rainbow trout and Atlantic cod [47]. The RVM of Atlantic salmon and lumpfish was also comparable to that previously reported for these species $(0.076 \%$ for Atlantic salmon [ 48 ] and $0.088 \%$ for lumpfish [49]).

\subsection{Citrate Synthase Activity}

The activity of CS in the heart of $\mathrm{Mb}^{-}$lumpfish was similar or greater than that of the other two $\mathrm{Mb}^{+}$species $\left(5.1 \mu \mathrm{mol} g\right.$ tissue $\mathrm{e}^{-1} \mathrm{~min}^{-1} \mathrm{vs.} 3.8$ and 6.5 in the sculpin and salmon, respectively; Table 1). Thus, the loss of $\mathrm{Mb}$ in $\mathrm{Hb}^{+}$species was not associated with a reduced aerobic metabolic capacity, and this agrees with the literature $[12,17,21]$. Interestingly, the expression of $\mathrm{Mb}$ was associated with a greater $\mathrm{CS}$ activity in $\mathrm{Hb}^{-}$ icefishes [50], a trait that does not appear to be shared with $\mathrm{Hb}^{+}$fishes. In our study, CS activity was negatively correlated with these species' RVM and P:O ratio (Supplementary Figure S3 and Figure 1D), and these data suggest that increased CS activity may be needed in fish with smaller hearts and/or that have a lower efficiency of oxidative phosphorylation. However, measurements of the myocardial oxygen consumption and power output of these hearts need to be performed before the relationship between CS, ventricular size, heart function, and myocardial efficiency can be elucidated.

\subsection{Relationship between $\mathrm{Mb}$ Content and Mitochondrial Function}

Differences in mitochondrial respiration and coupling (OXPHOS, LEAK and the resulting RCR) between the species in this study were only observed when stimulating the ETS with CI substrates (Figure 1). This inter-specific variation in CI functionality agrees with CI being an important site of physiological plasticity. For example, inter-specific variation in hypoxia tolerance has been related to the CI capacity of mitochondria in the sculpin brain [51], and this latter parameter was shown to be associated with intraspecific variation in the temperature-dependent mitochondrial function of Atlantic salmon hearts $[29,52]$. Cardiac mitochondria from lumpfish had OXPHOS-I and RCR-I respiration 
values that were lower as compared with the high activity $\mathrm{Mb}^{+}$salmon and the sedentary $\mathrm{Mb}^{+}$sculpin, respectively (Figure $1 \mathrm{~A}, \mathrm{C}$ ).

$\mathrm{S}$-nitrosation of $\mathrm{CI}$ due to the absence of the $\mathrm{NO}$ scavenger $\mathrm{Mb}$ in lumpfish may contribute to this difference in CI capacity. S-nitrosation of CI in mitochondria from the heart of freshwater turtles (Trachemys scripta) decreased ROS production and CI activity [8]. In support of this hypothesis, ROS production (expressed as pmol $\mathrm{H}_{2} \mathrm{O}_{2} \mathrm{mg}_{\text {protein }}{ }^{-1} \mathrm{~s}^{-1}$ ) under OXPHOS-I in lumpfish was slightly $(\sim 10 \%)$ lower than in the salmon, and significantly lower than in the sculpin $\left(0.185\right.$ vs. 0.200 and $0.226 \mathrm{pmol} \mathrm{H}_{2} \mathrm{O}_{2} \mathrm{mg}_{\text {protein }}{ }^{-1} \mathrm{~s}^{-1}$, respectively; Figure 2B). In contrast, sculpin mitochondria had the highest ROS production/release rate during LEAK-I and -I+II, and the loss of Mb was not associated with an increased ROS production/release rate under these states (Figure 2). This finding is consistent with the study of $\mathrm{O}^{\prime}$ Brien et al. (2019). These authors showed that variation in $\mathrm{Mb}$ expression in five species of notothenioid fishes was not associated with oxidative stress/damage in the ventricle [50]. This may be because inter-specific ROS scavenging by $\mathrm{Mb}^{+}$and $\mathrm{Mb}^{-}$fishes may only be relevant/observed under conditions of limited oxygen. Indeed, high $\mathrm{Mb}$ content was previously shown to be beneficial for scavenging ROS and NO under conditions of reduced oxygen supply [53,54].No differences in myocardial oxygen consumption were observed between the two $\mathrm{Mb}^{+}$species and the $\mathrm{Mb}^{-}$lumpfish after addition of the CII substrate succinate [i.e., in OXPHOS-I+II (State 3), LEAK-I+II (State 4) and the resulting RCR-I+II (State 3/State 4)] (Figure 1). Comparable ETS capacity in species that differ in $\mathrm{Mb}$ content agrees with a previous study that reported similar activities of key enzymes of energy metabolism in the hearts of the myoglobin-rich sea raven (Hemitripterus americanus) and the myoglobin-poor ocean pout (Macrozoarces americanus) at high $\mathrm{PO}_{2}$ [21] However, Legate et al. [22] found that while the $\mathrm{O}_{2}$ consumption of isolated myocytes was comparable in these two species at high $\mathrm{PO}_{2} \mathrm{~s}$, differences arose at low $\mathrm{PO}_{2}$ levels. Therefore, although the $\mathrm{P}_{50}$ for mitochondrial respiration is very low (5-20 times less than the half $\mathrm{O}_{2}$ saturation point of $\mathrm{Mb}$; [55]), it is possible that the loss of $\mathrm{Mb}$ may only be important under low/limiting oxygen $\left(\mathrm{PO}_{2}\right)$ conditions.

We reported P:O ratios of $\sim 3-3.5$ with glutamate, malate and pyruvate for the cardiac mitochondria of all three fish species (Figure 1D). These P:O ratios are high as compared to values reported with pyruvate and malate alone ( 2.5; [56]), and are likely due to glutamate dehydrogenase generating additional NADH as glutamate is converted to $\alpha$-ketoglutarate. The amount of substrate-level phosphorylation by glutamate is unknown [56], but in dog mitochondria, glutamate $\mathrm{P}: \mathrm{O}$ ratios were also over 3 [57]. The P:O ratio for lumpfish was the same as for salmon, which had a nearly identical RVM, and this suggests that oxidative phosphorylation is not influenced by the presence/absence of $\mathrm{Mb}$. These results contrast with that obtained with C2C12 cells derived from mice myoblasts [58], where cells made to overexpress $\mathrm{Mb}$ showed an improvement in the efficiency of producing ATP from ADP.

No clear patterns between oxidative capacity, mitochondrial function or oxidative status and $\mathrm{Mb}$ content were apparent. This result supports the findings of previous studies which showed that aerobic capacity was comparable amongst low activity species despite great differences in $\mathrm{Mb}$ content when measured at high $\mathrm{PO}_{2}$ [12,20-22].

\subsection{Relationship between Myoglobin Content and the NOS/NO System}

We found a positive relationship between NOS activity and cardiac $\mathrm{Mb}$ content when the data for all three species were combined (Figure 5A,B). A similar relationship was previously established between NOS activity and circulating $[\mathrm{Hb}]$ in red- and white-blooded Antarctic notothenioid fishes [23]. Hence, there is growing evidence that reduced NOS activity is a common feature of fishes lacking one of the NO scavengers $\left(\mathrm{Hb}^{-}\right.$and/or $\mathrm{Mb}^{-}$). The physiological consequences of a reduction in NOS activity should be further investigated. It is possible that $\mathrm{Mb}^{-}$fish decrease NOS activity to preclude a higher constitutive NO-tone due to the absence of potent $\mathrm{NO}$ scavengers. Indeed, a constitutive NO tone has been shown in several red-blooded fish species to affect both basal mitochondrial respiration [14] and myocardial contractility [59]. Furthermore, it remains unclear whether 
decreasing NOS activity mitigates the accumulation of NOx (nitrite/nitrate) in $\mathrm{Hb}^{-} \mathrm{Mb}^{-}$ fishes. Plasma nitrite has been shown to reflect NOS activity in mammals, and is recognized as a useful indicator of NOS activity/NO production [60]. However, NOx levels in the plasma of $C$. gunnari $\left(\mathrm{Hb}^{-} \mathrm{Mb}^{+}\right)$were comparable to those in three $\mathrm{Hb}^{+}$notothenioids with higher NOS activity (L. kempi, N. coriiceps and G. gibberifrons), and even higher plasma NOx was measured in C. aceratus $\left(\mathrm{Hb}^{-} \mathrm{Mb}^{-}\right)$despite it having a lower NOS activity [23]. It is possible that NOx in the plasma is influenced by the loss of the circulating NO scavenger $\mathrm{Hb}$, but the influence of $\mathrm{Mb}$ concentration on plasma NOx is unlikely. In addition, differences inNOx levels were not investigated here as it can be greatly influenced by a species diet, its nitrite susceptibility and concentrations in the environment [61], and this deserves further study.

Importantly, the $\mathrm{O}_{2}$ affinity of $\mathrm{Mb}$ determines this heme's function as a $\mathrm{NO}$ scavenger and producer, and may result in different NOx levels and effects. This is illustrated by the different amount of nitrite accumulation, and effects, at the same $\mathrm{O}_{2}$ tension in the myocardium of trout (low affinity Mb) vs. goldfish (high affinity Mb) [14]. Further, NOx content can also be influenced by the various sources of nitrite in fishes [61], and the up-regulation of other $\mathrm{NO} /$ nitrite/nitrate pathways in $\mathrm{Mb}^{-}$and/or $\mathrm{Hb}^{-}$species. In $\mathrm{Mb}^{-}$ mice, xanthine oxidoreductase (XOR)-related pathways are up-regulated to compensate for the lack of $\mathrm{Mb}$ [2]. In addition, negative-feedback regulation of iNOS (i.e., NOS2) gene expression by nitrite has previously been reported in brown trout [62], and this suggests that fish with higher $\mathrm{NO}_{X}$ may have lower NOS activity. To our knowledge, constitutive NO tone and its modulation by NOx level and NOS activity have not been examined in $\mathrm{Mb}^{-}$ and $\mathrm{Mb}^{+}$red-blooded fish species. However, differential modulation of basal mitochondrial respiration and cardiac function can be expected. The first evidence of the differential modulation of mitochondrial respiration is the difference in mitochondrial sensitivity to inhibition by $\mathrm{NO}$ (NO IC 50 ; Figure 4). In this study, a higher concentration of $\mathrm{NO}$ was required to reduce mitochondrial respiration by half in the $\mathrm{Mb}^{+}$salmon and sculpin as compared to the $\mathrm{Mb}^{-}$lumpfish (Figures 4 and $5 \mathrm{C}$ ). This change in mitochondrial sensitivity to $\mathrm{NO}$ is in line with the enhanced sensitivity to $\mathrm{NO}$, and activation of downstream pathways that regulate $\mathrm{NO}$, in $\mathrm{Mb}^{-}$mice $[2,63,64]$. In order to preserve $\mathrm{NO}$ and $\mathrm{O}_{2}$ homeostasis in the absence of this ' $\mathrm{O}_{2}$ carrier-NO scavenger/producer', NOS activity and mitochondrial NO sensitivity must be finely tuned. The positive correlation between NO $\mathrm{IC}_{50}$ and NOS activity in the ventricle of our fishes support this hypothesis (Figure 5D). Indeed, in the present study, low $\mathrm{NO} \mathrm{IC}_{50}$ was also associated with low ventricular NOS activity, and these parameters were decreased by $30-40 \%$ in the $\mathrm{Mb}^{-}$lumpfish (Figure $4 \mathrm{~B}$ and Table 2). In addition, our previous study [29] and that of Jørgensen et al. [65] provide compelling evidence that NOS activity and mitochondrial NO IC $\mathrm{In}_{50}$ in the salmon heart are synchronized/simultaneously adjusted. Specifically, these two studies collectively show that cold-acclimated salmon have low NOS activity and a lower NO IC 50 , whereas warmacclimated had higher values for these two parameters. The lack of $\mathrm{Mb}$ in the lumpfish heart may have required a reduction in NOS activity and an adjustment of the NO IC 50 to preserve $\mathrm{NO}$ homeostasis, and this may be a strategy employed by other $\mathrm{Mb}^{-}$fish to preserve NO homeostasis and the regulation of mitochondrial and cardiac function. NO concentration must be kept under tight control/in a fine balance to exert its physiological function while avoiding toxicity (see [66] for a review 'on how mammals and fish maintain NO homeostasis, both through NOS enzymes and globins'). Generation of sufficient NO levels to regulate important cardiovascular and mitochondrial functions is crucial, and may explain why an increase in sensitivity to $\mathrm{NO}$ (i.e., a lower $\mathrm{NO} \mathrm{IC}_{50}$ ) might be of benefit to $\mathrm{Mb}^{-}$fish.

Interestingly, the $\mathrm{NO} \mathrm{IC}_{50}$ values for the three species appeared to closely match their hypoxia tolerance (critical oxygen tension, $\mathrm{P}_{\text {crit }}$ ). For example, the $\mathrm{P}_{\text {crit }}$ and $\mathrm{NO} \mathrm{IC}_{50}$ values for the two $\mathrm{Mb}^{+}$species (salmon and sculpin) are $40 \%$ of air saturation (air sat.) [67-69] and $58 \mathrm{nmol} \mathrm{L}^{-1}$ vs. $33 \%$ air sat. [44] and $66 \mathrm{nmol} \mathrm{L}^{-1}$. Further, the lumpfish is the least hypoxia tolerant of the species studied, with a $\mathrm{P}_{\text {crit }}$ of $54.4 \%$ air sat. [70] and an NO IC 50 of 
$44 \mathrm{nmol} \mathrm{L}^{-1}$, and we previously measured an $\mathrm{NO} \mathrm{IC}_{50}$ value of $126 \mathrm{nmol} \mathrm{L}^{-1}$ in sablefish (Anoplopoma fimbria) [28], a very hypoxia tolerant species with a $\mathrm{P}_{\text {crit }}$ of $16 \%$ air sat. [71]. Hence, mitochondrial sensitivity to NO (i.e., its $\mathrm{IC}_{50}$ ) may also be a good marker/indicator of a species hypoxia tolerance. This hypothesis is not surprising as both $\mathrm{NO}$ and $\mathrm{Mb}$ (and their interactions) play a critical role in fish hypoxia tolerance [72,73].

No significant relationships could be established between NOS activity measured in the mitochondrial suspensions and mitochondrial NO IC 50 or ventricular NOS activity (Figure 5E,F). The existence of mitochondrial NOS (mtNOS), identified as a $\mathrm{nNOS}$ by most studies, and its functional role in regulating mitochondrial function is still being debated [74-77]. Mitochondrial NOS activity in our $\mathrm{Hb}^{+} \mathrm{Mb}^{+}$fish $(0.15-0.10 \mathrm{nmol} \mathrm{mg}$ protein $^{-1} \mathrm{~min}^{-1}$ ) is slightly lower than that measured in porcine heart mitochondria (0.22 nmol mg protein $\left.{ }^{-1} \min ^{-1} ;[78]\right)$. We, however, cannot rule out that contamination of the mitochondrial preparation with cytosolic NOS resulted in 'apparent' mtNOS activity. Whether mitochondrial NOS is a significant source of NO in the fish heart, and modulates oxidative phosphorylation, should be confirmed by evaluating the effects of substrates and inhibitors of NOS on mitochondrial respiration at low (physiologically relevant) $\mathrm{O}_{2}$ levels [as $\mathrm{NO}$ is outcompeted for binding to $\mathrm{CIV}$ at high $\mathrm{O}_{2}$ /in air-saturated solutions].

Studies on red-blooded fishes with differing cardiac Mb levels may help to improve our understanding of the role of $\mathrm{Mb}$ in $\mathrm{NO}$ homeostasis and signalling, and how they mediate mitochondrial and cardiac function. Overall, our data support the idea that compensatory mechanisms are at play in $\mathrm{Hb}^{+}$fishes that preserve $\mathrm{NO}$ and $\mathrm{O}_{2}$ homeostasis, as reported in $\mathrm{Mb}^{-}$mice [2] and in $\mathrm{Hb}^{-}$icefishes [24]. In red-blooded fishes, the loss of $\mathrm{Mb}$ was associated with lower NOS activity but an increased sensitivity to $\mathrm{NO}$ (a lower $\mathrm{IC}_{50}$; at least at the mitochondrial level). These data support the concept that NO is a 'master controller' of physiological traits in species lacking globins [17], and that globins play a critical role in NO homeostasis [66].

\section{Conclusions}

This study explored whether the presence/absence of $\mathrm{Mb}$ correlates with oxidative capacity and aspects of the NOS/NO system in the myocardium and mitochondria of red-blooded fish species. Overall, we report a reduction in NOS activity and an increase in the sensitivity to $\mathrm{NO}$ (at least at the mitochondrial level) in the $\mathrm{Mb}^{-}$lumpfish as compared to the $\mathrm{Mb}^{+}$salmon and sculpin. These adjustments in mitochondrial sensitivity to $\mathrm{NO}$ and cardiac NOS activity likely compensate for the loss of $\mathrm{Mb}$ (an important NO scavenger and producer in cardiac tissue), and ensure that mitochondrial function is finely tuned under various conditions. This comparative study using $\mathrm{Hb}^{+}$species with differing $\mathrm{Mb}$ content adds greatly to our knowledge of the dynamic and complex relationships between globins and NO, and adds further insights into how the heart deals with limitations in oxygen supply.

Supplementary Materials: The following are available online at https://www.mdpi.com/article/10 .3390/antiox10071072/s1. Figure S1: Representative recording of Experiment 1. Figure S2: Representative recording of Experiment 2. Figure S3: Relationships between ventricular citrate synthase (CS) activity, relative ventricular mass (RVM) and mitochondrial efficiency (P:O ratio) of Atlantic salmon, short-horned sculpin and lumpfish.

Author Contributions: A.K.G., W.R.D. and L.G. conceived the study; L.G., K.A.C., A.K.G. and W.R.D. designed the experiments; L.G. and K.A.C. conducted the experiments; L.G. and K.A.C. analyzed the data; L.G. drafted the manuscript. All authors have read and agreed to the published version of the manuscript.

Funding: Research funding was provided to A.K.G. by the Ocean Frontier Institute through an award from the Canada First Research Excellence Fund, and to A.K.G. and W.R.D. through the Natural Science and Engineering Council of Canada's Discovery Grant program. 
Institutional Review Board Statement: All animal protocols followed the guidelines established by the Canadian Council on Animal Care, and were approved by the Institutional Animal Care Committee of Memorial University of Newfoundland (Protocol no. 16-92-KG).

Informed Consent Statement: Not applicable.

Data Availability Statement: The data presented in this study are available on request from the corresponding author.

Acknowledgments: We thank Danny Boyce for providing the lumpfish used in this study and the staff of the Joe Brown Aquatic Research Building (JBARB) (Ocean Sciences Centre, OSC, Memorial University, NL) for assistance with lumpfish care and husbandry, Rebeccah Sandrelli and Ellen Peroni for assistance with Atlantic salmon care and husbandry, and the Field Services Unit of the OSC for the collection of short-horned sculpin.

Conflicts of Interest: The authors declare no conflict of interest.

\section{References}

1. Moncada, S.; Higgs, A. The L-arginine-Nitric oxide pathway. N. Engl. J. Med. 1993, 329, 2002-2012. [CrossRef]

2. Park, J.W.; Piknova, B.; Dey, S.; Noguchi, C.T.; Schechter, A.N. Compensatory mechanisms in myoglobin deficient mice preserve NO homeostasis. Nitric Oxide 2019, 90, 10-14. [CrossRef] [PubMed]

3. Brunori, M. Nitric oxide, cytochrome c oxidase and myoglobin: Competition and reaction pathways. Trends Biochem. Sci. 2001, 26, 21-23. [CrossRef]

4. Flögel, U.; Fago, A.; Rassaf, T. Keeping the heart in balance: The functional interactions of myoglobin with nitrogen oxides. J. Exp. Biol. 2010, 213, 2726-2733. [CrossRef]

5. Kamga, C.; Krishnamurthy, S.; Shiva, S. Myoglobin and mitochondria: A relationship bound by oxygen and nitric oxide. Nitric Oxide 2012, 26, 251-258. [CrossRef]

6. Shiva, S.; Huang, Z.; Grubina, R.; Sun, J.; Ringwood, L.A.; MacArthur, P.H.; Xu, X.; Murphy, E.; Darley-Usmar, V.M.; Gladwin, M.T. Deoxymyoglobin is a nitrite reductase that generates nitric oxide and regulates mitochondrial respiration. Circ. Res. 2007, 100, 654-661. [CrossRef]

7. Brown, G.C. Regulation of mitochondrial respiration by nitric oxide inhibition of cytochrome c oxidase. Biochim. Biophys. Acta 2001, 1504, 46-57. [CrossRef]

8. Bundgaard, A.; James, A.M.; Joyce, W.; Murphy, M.P.; Fago, A. Suppression of reactive oxygen species generation in heart mitochondria from anoxic turtles: The role of complex I S-nitrosation. J. Exp. Biol. 2018, 221, jeb174391. [CrossRef] [PubMed]

9. Gödecke, A. On the impact of NO-globin interactions in the cardiovascular system. Cardiovasc. Res. 2006, 69, 309-317. [CrossRef]

10. Massion, P.B.; Feron, O.; Dessy, C.; Balligand, J.L. Nitric oxide and cardiac function: Ten years after, and continuing. Circ. Res. 2003, 93, 388-398. [CrossRef]

11. Hendgen-Cotta, U.B.; Kelm, M.; Rassaf, T. Myoglobin functions in the heart. Free Radic. Biol. Med. 2014, 73, 252-259. [CrossRef]

12. Sidell, B.D.; Driedzic, W.R.; Stowe, D.B.; Johnston, I.A. Biochemical correlations of power development and metabolic fuel preferenda in fish hearts. Physiol. Zool. 1987, 60, 221-232. [CrossRef]

13. Cerra, M.C.; Angelone, T.; Parisella, M.L.; Pellegrino, D.; Tota, B. Nitrite modulates contractility of teleost (Anguilla anguilla and Chionodraco hamatus, i.e. the Antarctic hemoglobinless icefish) and frog (Rana esculenta) hearts. Biochim. Biophys. Acta Bioenerg. 2009, 1787, 849-855. [CrossRef] [PubMed]

14. Pedersen, C.L.; Faggiano, S.; Helbo, S.; Gesser, H.; Fago, A. Roles of nitric oxide, nitrite and myoglobin on myocardial efficiency in trout (Oncorhynchus mykiss) and goldfish (Carassius auratus): Implications for hypoxia tolerance. J. Exp. Biol. 2010, 213, 2755-2762. [CrossRef] [PubMed]

15. Pellegrino, D.; Palmerini, C.A.; Tota, B. No hemoglobin but NO: The icefish (Chionodraco hamatus) heart as a paradigm. J. Exp. Biol. 2004, 207, 3855-3864. [CrossRef] [PubMed]

16. Driedzic, W.R. The fish heart as a model system for the study of myoglobin. Comp. Biochem. Physiol. 1983, 76, 487-493. [CrossRef]

17. Sidell, B.D.; O'Brien, K.M. When bad things happen to good fish: The loss of hemoglobin and myoglobin expression in Antarctic icefishes. J. Exp. Biol. 2006, 209, 1791-1802. [CrossRef]

18. Macqueen, D.J.; De La Serrana, D.G.; Johnston, I.A. Cardiac myoglobin deficit has evolved repeatedly in teleost fishes. Biol. Lett. 2014, 10, 20140225. [CrossRef]

19. O'Brien, K.M.; Sidell, B.D. The interplay among cardiac ultrastructure, metabolism and the expression of oxygen-binding proteins in Antarctic fishes. J. Exp. Biol. 2000, 203, 1287-1297. [CrossRef] [PubMed]

20. Bailey, J.R.; Sephton, D.H.; Driedzic, W.R. Oxygen uptake by isolated perfused fish hearts with differing myoglobin concentrations under hypoxic conditions. J. Mol. Cell. Cardiol. 1990, 22, 1125-1134. [CrossRef]

21. Driedzic, W.R.; Stewart, J.M. Myoglobin content and the activities of enzymes of energy metabolism in red and white fish hearts. J. Comp. Physiol. Part B 1982, 149, 67-73. [CrossRef]

22. Legate, N.J.N.; Bailey, J.R.; Driedzic, W.R. Oxygen consumption in myoglobin-rich and myoglobin-poor isolated fish cardiomyocytes. J. Exp. Zool. 1998, 280, 269-276. [CrossRef] 
23. Beers, J.M.; Borley, K.A.; Sidell, B.D. Relationship among circulating hemoglobin, nitric oxide synthase activities and angiogenic poise in red- and white-blooded Antarctic notothenioid fishes. Comp. Biochem. Physiol. Part A 2010, 156, 422-429. [CrossRef]

24. Garofalo, F.; Pellegrino, D.; Amelio, D.; Tota, B. The Antarctic hemoglobinless icefish, fifty five years later: A unique cardiocirculatory interplay of disaptation and phenotypic plasticity. Comp. Biochem. Physiol. Part A 2009, 154, 10-28. [CrossRef] [PubMed]

25. Morlá, M.; Agusti, A.G.N.; Rahman, I.; Motterlini, R.; Saus, C.; Morales-Nin, B.; Company, J.B.; Busquets, X. Nitric oxide synthase type I (nNOS), vascular endothelial growth factor (VEGF) and myoglobin-like expression in skeletal muscle of Antarctic icefishes (Notothenioidei: Channichthyidae). Polar Biol. 2003, 26, 458-462. [CrossRef]

26. Grove, T.J.; Sidell, B.D. Myoglobin deficiency in the hearts of phylogenetically diverse temperate-zone fish species. Can. J. Zool. 2002, 80, 893-901. [CrossRef]

27. Turner, J.D.; Driedzic, W.R. Mechanical and metabolic response of the perfused isolated fish heart to anoxia and acidosis. Can. J. Zool. 1980, 58, 886-889. [CrossRef]

28. Gerber, L.; Clow, K.A.; Katan, T.; Emam, M.; Leeuwis, R.H.J.; Parrish, C.C.; Gamperl, A.K. Cardiac mitochondrial function, nitric oxide sensitivity and lipid composition following hypoxia acclimation in sablefish. J. Exp. Biol. 2019. [CrossRef] [PubMed]

29. Gerber, L.; Clow, K.A.; Gamperl, A.K. Acclimation to warm temperatures has important implications for mitochondrial function in Atlantic salmon (Salmo salar). J. Exp. Biol. 2021, 224, jeb.236257. [CrossRef]

30. Fasching, M.; Gnaiger, E. O2k Quality Control 2: Instrumental oxygen background correction and accuracy of oxygen flux. Mitochondrial Physiol. Netw. 2018, 14, 1-14.

31. Gnaiger, E. O2k Quality Control 1: Polarographic oxygen sensors and accuracy of calibration. Mitochondrial Physiol. Netw. 2018, 6, $1-20$.

32. Krumschnabel, G.; Fontana-Ayoub, M.; Fasching, M.; Gnaiger, E. O2k-FluoRespirometry: HRR and simultaneous determination of $\mathrm{H} 2 \mathrm{O} 2$ production with Amplex UltraRed. Mitochondrial Physiol. Netw. 2019, 20, 1-6.

33. Makrecka-Kuka, M.; Krumschnabel, G.; Gnaiger, E. High-resolution respirometry for simultaneous measurement of oxygen and hydrogen peroxide fluxes in permeabilized cells, tissue homogenate and isolated mitochondria. Biomolecules 2015, 5, 1319-1338. [CrossRef] [PubMed]

34. Fasching, M.; Gnaiger, E. O2k-MultiSensor system with amperometric sensors: NO, H2S, H2O2. Mitochondrial Physiol. Netw. 2016, $15,1-11$.

35. Hevel, J.M.; Marletta, M.A. Nitric oxide synthase assays. Methods Enzymol. 1994, 233, 250-258. [CrossRef]

36. Gross, S.S. Microtiter plate assay for determining kinetics of nitric oxide synthesis. Methods Enzymol. 1996, 268, 159-168. [CrossRef] [PubMed]

37. Murphy, M.E.; Noack, E. Nitric oxide assay using hemoglobin method. Methods Enzymol. 1994, 233, 240-250. [CrossRef]

38. Antonini, E.; Brunori, M. Hemoglobin and Myoglobin in Their Reactions with Ligands; American Elsevier: New York, NY, USA, 1971; p. 436.

39. Treberg, J.R.; MacCormack, T.J.; Lewis, J.M.; Almeida-Val, V.M.F.; Val, A.L.; Driedzic, W.R. Intracellular glucose and binding of hexokinase and phosphofructokinase to particulate fractions increase under hypoxia in heart of the Amazonian armored catfish (Liposarcus pardalis). Physiol. Biochem. Zool. 2007, 80, 542-550. [CrossRef] [PubMed]

40. Sidell, B.D. Responses of goldfish (Carassius auratus, L.) muscle to acclimation temperature: Alterations in biochemistry and proportions of different fiber. Physiol. Zool. 1980, 53, 98-107. [CrossRef]

41. Ewart, H.S.; Driedzic, W.R. Enzymes of energy metabolism in salmonid hearts: Spongy versus cortical myocardia. Can. J. Zool. 1987, 65, 623-627. [CrossRef]

42. Jones, D.R.; Randall, D.J. The respiratory and circulatory systems during exercise. In Fish physiology; Hoar, W.S., Randall, D.J., Eds.; Academic Press: New York, NY, USA, 1978; pp. 425-501.

43. Poupa, O.; Gesser, H.; Jonsson, S.; Sullivan, L. Coronary-supplied compct shell of ventricular myocardium in salmonids: Growth and enzyme pattern. Comp. Biochem. Physiol. A Mol. Integr. Physiol. 1974, 48, 85-95. [CrossRef]

44. Mandic, M.; Todgham, A.E.; Richards, J.G. Mechanisms and evolution of hypoxia tolerance in fish. Proc. R. Soc. B Biol. Sci. 2009, 276, 735-744. [CrossRef]

45. Farrell, A.P.; Smith, F. Cardiac form, function and physiology. In The Cardiovascular System: Morphology, Control and Function; Gamperl, A.K., Gillis, T.E., Farrell, A.P., Brauner, C.J., Eds.; Elsevier Inc.: Cambridge, MA, USA, 2017; Volume 36, pp. 155-264.

46. Santer, R.M. Morphology and innervation of the fish heart. In Advances in Anatomy Embryology and Cell Biology; Springer: Berlin, Germany, 1985; pp. 1-97.

47. Farrell, A.P.; Altimiras, J.; Franklin, C.E.; Axelsson, M. Niche expansion of the shorthorn sculpin (Myoxocephalus scorpius) to arctic waters is supported by a thermal independence of cardiac performance at low temperature. Can. J. Zool. 2013, 91, 573-580. [CrossRef]

48. Penney, C.M.; Nash, G.W.; Kurt Gamperl, A. Cardiorespiratory responses of seawater-acclimated adult Arctic char (Salvelinus alpinus) and Atlantic salmon (Salmo salar) to an acute temperature increase. Can. J. Fish. Aquat. Sci. 2014, 71, 1096-1105. [CrossRef]

49. Hvas, M.; Folkedal, O.; Imsland, A.; Oppedal, F. Metabolic rates, swimming capabilities, thermal niche and stress response of the lumpfish, Cyclopterus lumpus. Biol. Open 2018, 7, 1-9. [CrossRef] [PubMed]

50. O’Brien, K.M.; Crockett, E.L.; Philip, J.; Oldham, C.A.; Hoffman, M.; Kuhn, D.E.; Barry, R.; McLaughlin, J. The loss of hemoglobin and myoglobin does not minimize oxidative stress in Antarctic icefishes. J. Exp. Biol. 2018, 221, jeb.162503. [CrossRef] [PubMed] 
51. Lau, G.Y.; Arndt, M.; Murphy, M.P.; Richards, J.G. Species and tissue specific differences in ROS metabolism to hypoxia- and hyperoxia-recovery exposure in marine sculpins. J. Exp. Biol. 2019, 222, jeb.206896. [CrossRef] [PubMed]

52. Gerber, L.; Clow, K.A.; Mark, F.C.; Gamperl, A.K. Improved mitochondrial function in salmon (Salmo salar) following high temperature acclimation suggests that there are cracks in the proverbial "ceiling". Sci. Rep. 2020, 10, 21636. [CrossRef]

53. Flögel, U.; Gödecke, A.; Klotz, L.; Schrader, J. Role of myoglobin in the antioxidant defense of the heart. FASEB J. 2004, 18, 1156-1158. [CrossRef]

54. Merx, M.W.; Gödecke, A.; Flögel, U.; Schrader, J. Oxygen supply and nitric oxide scavenging by myoglobin contribute to exercise endurance and cardiac function. FASEB J. 2005, 2, 1-15. [CrossRef]

55. Gnaiger, E.; Lassnig, B.; Kusnetsov, A.; Rieger, G.; Margreiter, R. Mitochondrial oxygen affinity, respiratory flux control and excess capacity of cytochrome c oxidase. J. Exp. Biol. 1998, 201, 1129-1139. [CrossRef] [PubMed]

56. Hinkle, P.C. P/O ratios of mitochondrial oxidative phosphorylation. Biochim. Biophys. Acta 2005, 1706, 1-11. [CrossRef]

57. Wilson, D.F.; Owen, C.; Mela, L.; Weiner, L. Control of mitochondrial respiration by the phosphate potential. Biochem. Biophys. Res. Commun. 1973, 53, 326-333. [CrossRef]

58. Yamada, T.; Takakura, H.; Jue, T.; Hashimoto, T.; Ishizawa, R.; Furuichi, Y.; Kato, Y.; Iwanaka, N.; Masuda, K. Myoglobin and the regulation of mitochondrial respiratory chain complex IV. J. Physiol. 2016, 594, 483-495. [CrossRef] [PubMed]

59. Carnevale, C.; Roberts, J.C.; Syme, D.A.; Gamperl, A.K. Hypoxic acclimation negatively impacts the contractility of steelhead trout (Oncorhynchus mykiss) spongy myocardium. Am. J. Physiol. Regul. Integr. Comp. Physiol. 2020, 318, R214-R226. [CrossRef]

60. Kleinbongard, P.; Dejam, A.; Lauer, T.; Rassaf, T.; Schindler, A.; Picker, O.; Scheeren, T.; Gödecke, A.; Schrader, J.; Schulz, R.; et al. Plasma nitrite reflects constitutive nitric oxide synthase activity in mammals. Free Radic. Biol. Med. 2003, 35, 790-796. [CrossRef]

61. Jensen, F.B. Nitrite disrupts multiple physiological functions in aquatic animals. Comp. Biochem. Physiol. A. Mol. Integr. Physiol. 2003, 135, 9-24. [CrossRef]

62. Jensen, F.B.; Gerber, L.; Hansen, M.N.; Madsen, S.S. Metabolic fates and effects of nitrite in brown trout under normoxic and hypoxic conditions: Blood and tissue nitrite metabolism and interactions with branchial NOS, Na+/K+-ATPase and hsp70 expression. J. Exp. Biol. 2015, 218, 2015-2022. [CrossRef]

63. Flögel, U.; Merx, M.W.; Gödecke, A.; Decking, U.K.M.; Schrader, J. Myoglobin: A scavenger of bioactive NO. Proc. Natl. Acad. Sci. USA 2001, 98, 735-740. [CrossRef]

64. Grange, R.W.; Isotani, E.; Lau, K.S.; Kamm, K.E.; Huang, P.L.; Stull, J.T. Nitric oxide contributes to vascular smooth muscle relaxation in contracting fast-twitch muscles. Physiol. Genom. 2001, 5, 35-44. [CrossRef] [PubMed]

65. Jørgensen, S.M.; Castro, V.; Krasnov, A.; Torgersen, J.; Timmerhaus, G.; Hevrøy, E.M.; Hansen, T.J.; Susort, S.; Breck, O.; Takle, H. Cardiac responses to elevated seawater temperature in Atlantic salmon. BMC Physiol. 2014, 14, 2. [CrossRef]

66. Rochon, E.R.; Corti, P. Globins and nitric oxide homeostasis in fish embryonic development. Mar. Genom. 2020, $49,100721$. [CrossRef] [PubMed]

67. Barnes, R.K.; King, H.; Carter, C.G. Hypoxia tolerance and oxygen regulation in Atlantic salmon, Salmo salar from a Tasmanian population. Aquaculture 2011, 318, 397-401. [CrossRef]

68. Stevens, E.D.; Sutterlin, A.; Cook, T. Respiratory metabolism and swimming performance in growth hormone transgenic Atlantic salmon. Can. J. Fish. Aquat. Sci. 1998, 55, 2028-2035. [CrossRef]

69. Remen, M.; Oppedal, F.; Imsland, A.K.; Olsen, R.E.; Torgersen, T. Hypoxia tolerance thresholds for post-smolt Atlantic salmon: Dependency of temperature and hypoxia acclimation. Aquaculture 2013, 416-417, 41-47. [CrossRef]

70. Ern, R.; Norin, T.; Gamperl, A.K.; Esbaugh, A.J. Oxygen dependence of upper thermal limits in fishes. J. Exp. Biol. 2016, 219, 3376-3383. [CrossRef]

71. Leeuwis, R.H.J.; Nash, G.W.; Sandrelli, R.M.; Zanuzzo, F.S.; Gamperl, A.K. The environmental tolerances and metabolic physiology of sablefish (Anoplopoma fimbria). Comp. Biochem. Physiol. Part A 2019, 231, 140-148. [CrossRef]

72. Gattuso, A.; Garofalo, F.; Cerra, M.C.; Imbrogno, S. Hypoxia tolerance in teleosts: Implications of cardiac nitrosative signals. Front. Physiol. 2018, 9, 1-13. [CrossRef]

73. Filice, M.; Mazza, R.; Leo, S.; Gattuso, A.; Cerra, M.C.; Imbrogno, S. The hypoxia tolerance of the goldfish (Carassius auratus) heart: The NOS/NO system and beyond. Antioxidants 2020, 9, 555. [CrossRef]

74. Giulivi, C.; Jose, J.; Boveris, A. Production of nitric oxide by mitochondria. J. Biol. Chem. 1998, 273, 11038-11043. [CrossRef]

75. Haynes, V.; Elfering, S.; Traaseth, N.; Giulivi, C. Mitochondrial nitric-oxide synthase: Enzyme expression, characterization, and regulation. J. Bioenerg. Biomembr. 2004, 36, 341-346. [CrossRef]

76. Aguirre, E.; López-Bernardo, E.; Cadenas, S. Functional evidence for nitric oxide production by skeletal-muscle mitochondria from lipopolysaccharide-treated mice. Mitochondrion 2012, 12, 126-131. [CrossRef]

77. Sakamuri, S.S.V.P.; Sperling, J.A.; Evans, W.R.; Dholakia, M.H.; Albuck, A.L.; Sure, V.N.; Satou, R.; Mostany, R.; Katakam, P.V.G. Nitric oxide synthase inhibitors negatively regulate respiration in isolated rodent cardiac and brain mitochondria. Am. J. Physiol. Heart Circ. Physiol. 2020, 318, H295-H300. [CrossRef]

78. French, S.; Giulivi, C.; Balaban, R.S. Nitric oxide synthase in porcine heart mitochondria: Evidence for low physiological activity. Am. J. Physiol. Heart Circ. Physiol. 2001, 280, H2863-H2867. [CrossRef] 